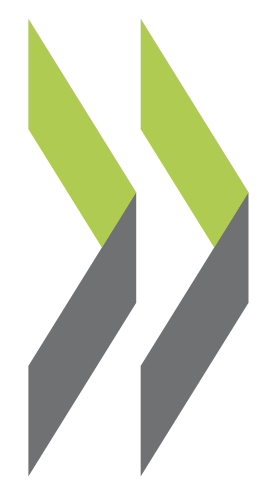

OECD Economics Department Working Papers No. 654

Monetary Transmission Mechanism in Central and Eastern Europe: Balázs Égert, Ronald MacDonald Surveying the Surveyable 
Organisation de Coopération et de Développement Économiques

Organisation for Economic Co-operation and Development

01-Dec-2008

ECONOMICS DEPARTMENT

English - Or. English

MONETARY TRANSMISSION MECHANISM IN CENTRAL AND EASTERN EUROPE: SURVEYING THE SURVEYABLE

ECONOMICS DEPARTMENT WORKING PAPERS No. 654

By Balázs Égert and Ronald MacDonald

All Economics Department Working Papers are available through OECD's internet web site at www.oecd.org/eco/Working Papers

JT03256604

Document complet disponible sur OLIS dans son format d'origine

Complete document available on OLIS in its original format 


\section{ABSTRACT/RESUMÉ}

\section{Monetary Transmission Mechanism in Central and Eastern Europe: Surveying the Surveyable}

This paper surveys recent advances in empirical studies of the monetary transmission mechanism (MTM), with special attention to Central and Eastern Europe (CEE). Our results indicate that the strength of the exchange rate pass-through substantially declined over time mainly due to a fall in inflation rates and to some extent due to the so-called composition effect. The asset price channel is weak and is likely to remain weak because of shallow stock and private bond markets and because of low stock and bond holdings of domestic household. House prices may become an exception with higher levels mortgage lending and with high owner occupancy ratios. While the credit channel could be a powerful channel of monetary transmission - as new funds raised on capital markets are close to zero in CEE - it is actually not, as both commercial banks and non-financial corporations can escape domestic monetary conditions by borrowing from their foreign mother companies. The moderately good news is, however, that those banks and firms are influenced by monetary policy in the euro area because their parent institutions are themselves subjected to the credit channel in the euro area.

JEL classifications: E31; E51; E58; F31; O11; P20.

Keywords: Monetary transmission, Central and Eastern Europe, credit channel, interest rate channel, interest-rate pass-through, exchange rate channel, exchange rate pass-through, asset price channel

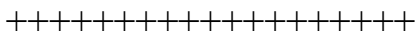

\section{Canaux de transmission de la politique monétaire dans les PECO: une revue de la littérature}

Ce papier vise à synthétiser la littérature empirique portant sur le mécanisme de transmission monétaire, et tout particulièrement dans les pays d'Europe centrale et orientale (PECO). Cette étude montre que l'effet du taux de change sur l'inflation a diminué au cours du temps principalement en raison de la baisse des taux d'inflation, mais aussi dans une certaine mesure suite à un effet dit de composition. Le canal des prix d'actifs est faible et le restera probablement en raison des marchés d'actions et de titres obligataires privés peu développés, mais aussi à cause d'un faible taux de détention d'actifs financiers par les ménages. En revanche, avec l'accroissement du nombre de prêts immobiliers et de ménages propriétaires de leur appartements, les prix immobiliers peuvent jouer un rôle plus important à l'avenir. Même si le canal du crédit devrait être un des canaux de transmission les plus puissants, sachant que le financement externe sur les marchés est quasiment nul dans les PECO, tel n'est pas le cas pour autant. La raison en est que les banques commerciales mais aussi les entreprises peuvent échapper aux conditions monétaires nationales par le biais de financements obtenus auprès de leurs maisons mères implantées à l'étranger. La nouvelle quelque peu encourageante est que les entreprises mères sont elles-mêmes contraintes par la politique monétaire de la zone euro, exportant ainsi les effets du canal du crédit dans les PECO.

JEL classifications : E31; E51; E58; F31; O11; P20.

Mots-clés : transmission monétaire, PECO, canal du crédit, canal du taux d'intérêt, canal du taux de change, canal des prix d'actifs.

\section{Copyright OECD, 2008}

Application for permission to reproduce or translate all, or part of, this material should be made to: Head of Publications Service, OECD, 2 rue André Pascal, 75775 Paris CEDEX 16. 


\section{TABLE OF CONTENTS}

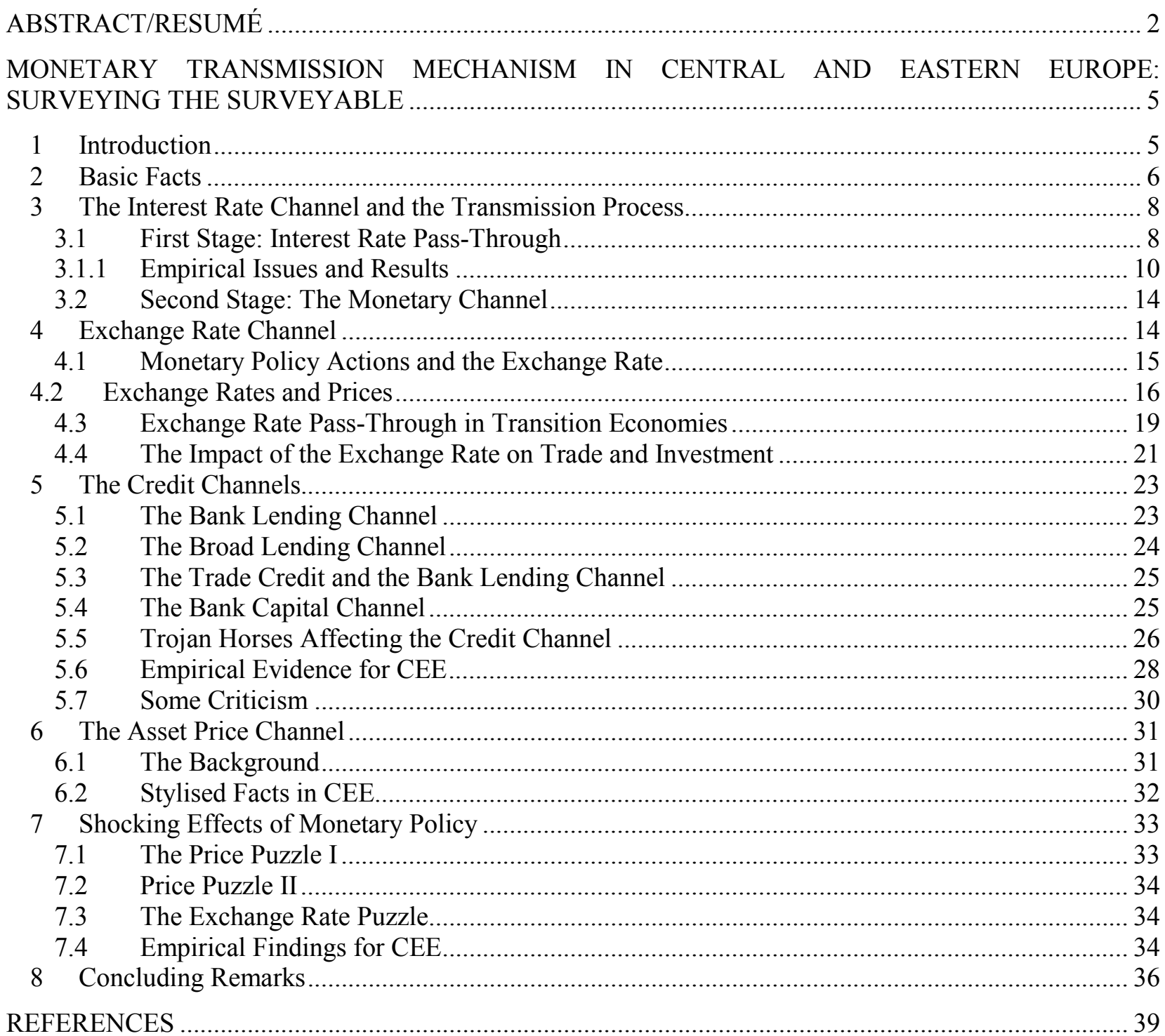




\section{ECO/WKP(2008)62}


ECO/WKP(2008)62

\title{
MONETARY TRANSMISSION MECHANISM IN CENTRAL AND EASTERN EUROPE: SURVEYING THE SURVEYABLE
}

\author{
By \\ Balázs Égert ${ }^{1}$ and Ronald MacDonald ${ }^{23}$
}

1

Introduction

1. Given its potential to affect the real economy, monetary policy has been subject to intense academic scrutiny over the years in the economics profession. Bernanke and Gertler (1995) deem the mechanism through which monetary policy actions are transmitted to the real economy as a black box. Interest in resolving this conundrum has given rise to a large body of theoretical work and to a plethora of empirical papers that seek to match theory with real data. The most traditional explanation for the link is the interest rate channel developed in textbook IS-LM models. However, the early observation that the interest rate channel cannot neatly explain output fluctuations has given birth to the credit channel literature (including the bank lending, the broad lending, the bank capital and the role of trade credit channels). Finally, asset prices, such as the exchange rate, stock and real estate prices are also believed to constitute a bridge between nominal and real variables, which has had important policy implications for the choice of variables in a central bank's interest rate rule when a central bank targets inflation. This paper analyzes the separate functioning of the distinct channels, but it also highlights possible interlinkages between the different channels through which they may magnify or counteract each others' influence in the monetary transmission mechanism (MTM). Chart 1 below gives a schematic overview of the different channels and the ways how they are interrelated.

2. There are at least two important reasons to study the monetary transmission mechanism in the transition economies of Central and Eastern Europe (CEE). First, a genuine and precise understanding of how fast, and to what extent, a change in the central bank's interest instrument modifies inflation lies at the heart of inflation targeting. An increasing number of transition countries are already making use of inflation targeting, or are planning to do so. Second, given the forthcoming full euro area participation of the countries that entered the EU in May 2004 and given the large gap in financial sector development between CEE and the euro area, it is of fundamental importance to evaluate whether monetary

1 OECD, Economics Department. Email: Balazs.EGERT@oecd.org

$2 \quad$ University of Glasgow. Email: R.MacDonald@lbss.gla.ac.uk

3 The paper benefited from comments from Markus Arpa, Peter Backé, Csilla Horváth, Felix Hüfner, Zoltán M. Jakab, Peter Jarrett, Rafal Kierzenowski, Markus Knell, Mihály M. Kovács, Charlotte Moeser, Márton Nagy, Klaus Schmidt-Hebbel, György Szapáry, Balázs Vonnák and participants of seminars held at the Magyar Nemzeti Bank, the Oesterreichische Nationalbank, the Deutsche Bundesbank, the Finance and Consumption Conference: Credit, Consumption and the Macro Economy (European University Institute) and an internal OECD seminar. This work started when Égert visited the Magyar Nemzeti Bank in 2005. We would like to thank three anonymous referees for their valuable comments. The usual disclaimer applies. The paper is forthcoming in the Journal of Economic Surveys. We also thank Irene Sinha for editorial assistance. 
transmission operates differently in CEE countries. Indeed, a homogeneous approach to monetary policy for CEE and euro area countries could lead to sharply different effects on the economies and what kind of new challenges the ECB will be facing in this context.

Chart 1. The Monetary Transmission Mechanism

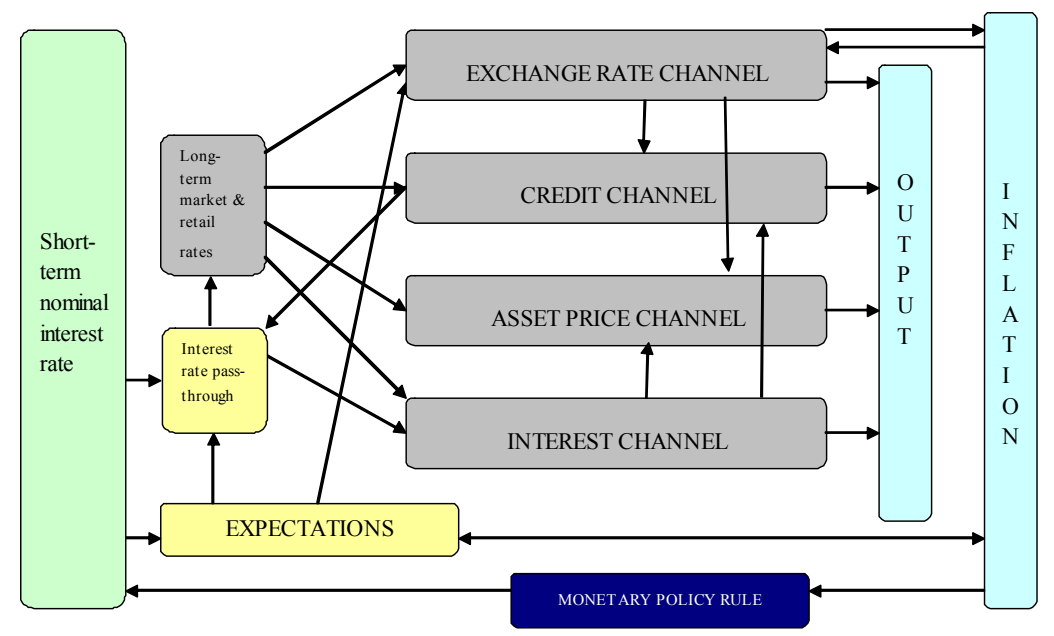

3. Despite the importance of these questions, the empirical literature dealing with CEE appears to be fragmented. This paper attempts to bring together different branches of the literature. In particular, we take stock of the empirical studies relating to CEE and present them systematically. In addition, we direct attention to potential pitfalls in the literature and assess the relative importance and the potential development of the different channels. Nevertheless, the current paper does not seek to assess the influence of financial crisis started in autumn 2008 and its aftermath on financial structures and thereby the transmission mechanism.

4. The paper is structured as follows. Section 2 provides an overview of the evolution of the monetary policy framework, Sections 3 to 6 survey the theoretical literature and summarize the empirical findings for the CEE transition economies for the interest channel, the exchange rate channel, the credit channel and the asset price channel, respectively. Section 7 analyzes studies based on the vector auto regression (VAR) methodology. Section 8 concludes by speculating on possible future developments of the different channels.

\section{Basic Facts}

5. Here we provide some basic information with regard to the general monetary policy framework and the inflation rate, the exchange rate regime in place and about the banking sector to make diverging/converging developments in the monetary transmission mechanism of different CEE countries easier to understand (Table 1a). Most transition economies started economic transformation with no or ad hoc monetary policy frameworks. Central banks were not independent and they had conflicting final objectives including foreign sustainability, output stabilization, financial stability and price stability. At the early stages, they were using the exchange rate as an intermediary target, in some cases coupled with monetary or credit targeting, and administrative instruments to achieve the targets (e.g. capital controls). 
Fixing the exchange rate was meant to anchor inflationary expectations in the aftermath of price liberalization that resulted in two or three digit inflation rates.

6. Monetary policy in transition economies has undergone profound change since economic transition started in the early 1990s. Coherent monetary policy frameworks were put in place with price stability being the single final objective. Central banks became independent. A number of countries have introduced inflation targeting over the last 10 years (Czech Republic, Poland, Hungary, and Romania). This, and full capital account liberalization led some countries to move from exchange rate pegs to managed or free floats. Others, like the Baltic States and Croatia, stuck to currency boards and pegs. Slovenia adopted the euro in 2007 and Slovakia will do so in 2009. The banking sector in most countries was privatized (mostly) with strong foreign involvement and financial markets started functioning (Table 1b), making the shift from administrative to market-based instruments of the central banks possible. All in all, improved monetary policy frameworks resulted in single-digit inflation rates, even though global trends (e.g. cheap imports from China) have played a role in it.

Table 1a. Monetary Policy Frameworks, Exchange Rate Regimes and Inflation Rates in Transition Economies, 1993-2008

\begin{tabular}{|c|c|c|c|c|c|c|}
\hline & \multicolumn{2}{|c|}{$\begin{array}{l}\text { Monetary policy } \\
\text { framework }\end{array}$} & \multicolumn{2}{|c|}{ Exchange rate regime } & \multicolumn{2}{|c|}{$\begin{array}{c}\text { Average annual } \\
\text { inflation }(\%)\end{array}$} \\
\hline \multicolumn{7}{|c|}{ Baltic countries } \\
\hline Estonia & $\mathrm{CB}$ & $\mathrm{CB}$ & $\mathrm{CB}$ & $\mathrm{CB}$ & 89.8 & 6.6 \\
\hline Lithuania & $\mathrm{CB}$, & $\mathrm{CB}$ & PEG & $\mathrm{CB}$ & 410.2 & 5.7 \\
\hline Latvia & ET & ET & PEG & PEG & 90.8 & 10.1 \\
\hline \multicolumn{7}{|c|}{ Central and Eastern Europe - 5} \\
\hline Czech Rep. & $\mathrm{ET}, \mathrm{MT}$ & IT & PEG & FLOAT & 20.7 & 2.9 \\
\hline Hungary & $\mathrm{ET}$ & IT & PEG & FLOAT & 22.5 & 8.0 \\
\hline Poland & ET & IT & PEG & FLOAT & 35.3 & 2.5 \\
\hline Slovakia & $\mathrm{ET}, \mathrm{MT}$ & IT & PEG & ERM-2 & 23.2 & 2.8 \\
\hline Slovenia & ET & ECB & UPEG & EURO & 32.9 & 3.6 \\
\hline \multicolumn{7}{|c|}{ South-eastern Europe } \\
\hline Bulgaria & $\mathrm{CT}, \mathrm{FT}$ & $\mathrm{CB}$ & FLOAT & $\mathrm{CB}$ & 73.1 & 8.4 \\
\hline Croatia & ET & ET & UPEG & IPEG & 15.4 & 2.9 \\
\hline Romania & & IT & PEG & FLOAT & 256.1 & 4.8 \\
\hline \multicolumn{7}{|c|}{ Former Soviet Union } \\
\hline Russia & NOMPF & ET & FLOAT & IPEG & 873.1 & 9.0 \\
\hline Ukraine & NOMPF & ET & & PEG & 5371.0 & 12.8 \\
\hline
\end{tabular}

Source: inflation data are obtained from the EBRD's website (http://www.ebrd.com/country/sector/econo/stats/index.htm); data for 2007 are preliminary estimates. Information on monetary policy and exchange rate regimes is taken from central bank publications and relying on national experts.

Note: monetary policy: $\mathrm{NOMPF}=$ no monetary policy framework, $\mathrm{CB}=$ currency board, $\mathrm{ET}=$ exchange rate targeting, $\mathrm{MT}=$ monetary targeting, $\mathrm{CT}=$ credit targeting, $\mathrm{IT}=$ inflation targeting.

Exchange rate regimes: $\mathrm{CB}=$ currency board, $\mathrm{PEG}=$ officially announced exchange rate peg, $\mathrm{IPEG}=$ unofficial exchange rate peg, $\mathrm{FLOAT}=$ managed or free float 
Table 1b. Factors amplifying or attenuating the interest rate pass-through, 2006

\begin{tabular}{|c|c|c|c|c|c|c|c|c|c|c|c|c|c|}
\hline & $\mathrm{CZ}$ & HU & PL & SK & SI & $\mathrm{EE}$ & LV & LT & BG & HR & ROM & RU & UA \\
\hline & \multicolumn{13}{|c|}{ State ownership (\% in total banking assets) } \\
\hline 1993 & 77.1 & 77.21 & 86.2 & 70.7 & 47.8 & 25.7 & & 53.6 & & 58.9 & & & \\
\hline \multirow[t]{2}{*}{2006} & 2.2 & 7.4 & & 1.1 & 12.6 & 0.0 & 4.4 & 0.0 & 1.8 & 4.2 & 50 & & 8.9 \\
\hline & \multicolumn{13}{|c|}{ Foreign ownership (\% in total banking assets) } \\
\hline 1993 & 7.3 & 9.4 & 2.8 & & & 0.4 & & & & & & & \\
\hline \multirow[t]{2}{*}{2006} & 84.7 & 82.9 & 74.3 & 97.0 & 29.5 & 99.1 & 62.9 & 91.8 & 80.1 & 90.8 & 87.9 & 12.1 & 35.0 \\
\hline & \multicolumn{13}{|c|}{ Bad loans (\% in total loans) } \\
\hline \multirow[t]{2}{*}{2006} & 3.8 & 3.0 & 8.3 & $5.5^{*}$ & 5.6 & 0.2 & 0.5 & 1.0 & 3.2 & 5.9 & 1.8 & 2.4 & 1.7 \\
\hline & \multicolumn{13}{|c|}{ Banking sector concentration - 5 largest banks (\% in total assets) } \\
\hline \multirow[t]{2}{*}{2004} & 64.0 & 52.7 & 50.2 & 66.5 & 64.1 & 98.6 & 62.4 & 78.9 & $47.0^{\mathrm{a}}$ & $58.0^{\mathrm{a}}$ & $66.0^{\mathrm{a}}$ & & \\
\hline & \multicolumn{13}{|c|}{ Domestic credit to private sector (\% of GDP) } \\
\hline 1993 & 51.0 & 26.5 & 12.2 & 28.8 & 22.1 & 10.1 & & 13.8 & & 37.7 & 3.1 & 11.8 & 1.4 \\
\hline \multirow[t]{2}{*}{2006} & 39.9 & 54.6 & 33.4 & 39.2 & 67.1 & 78.4 & 77.9 & 47.7 & 47.4 & 68.7 & 26.3 & 31.0 & 44.9 \\
\hline & \multicolumn{13}{|c|}{ Domestic credit to households (\% of GDP) } \\
\hline \multirow[t]{2}{*}{2006} & 16.5 & 18.5 & 15.6 & 13.1 & 17.0 & 38.7 & 38.0 & 17.9 & 16.6 & 38.2 & 11.2 & 7.1 & 15.3 \\
\hline & \multicolumn{13}{|c|}{ Of which mortgages (\% of GDP) } \\
\hline 2006 & 10.0 & 13.9 & 7.2 & 4.1 & 4.5 & 32.1 & 28.9 & 12.6 & 7.2 & 14.7 & 0.9 & 0.9 & \\
\hline
\end{tabular}

Source: EBRD Transition Indicators 2007. (http://www.ebrd.com/country/sector/econo/stats/index.htm), ECB (2005): EU Banking Structures, October, *2005

\section{The Interest Rate Channel and the Transmission Process}

7. The interest rate channel encapsulated in the traditional IS-LM model can be dissected into two distinct stages: (1) the transmission from short-term nominal interest rates to long-term real interest rates, and (2) the channel through which aggregate demand and production are affected by real interest rate developments.

\subsection{First Stage: Interest Rate Pass-Through}

8. Crucial to the effectiveness of any monetary policy action is, first, how changes in the monetary policy rate are transmitted onto market rates at the longer end of the maturity spectrum, and, second, how bank deposit and lending rates are affected by such a change in market rates.

9. The term structure of interest rates provides the connection between short- and long-term (market) nominal interest rates. The slope and the dynamics of the term structure can best be explained using a combination of standard theories, such as the liquidity preference view, according to which investors require a liquidity premium for holding less liquid (usually long-term) assets, or the market segmentation view, according to which short-term and long-term interest rates can be determined independently in segmented markets. More importantly, it is widely accepted that expectations are a key determinant of the shape of the yield curve. According to this view, long-term interest rates are obtained as an average of expected future short-term interest rates. This is often referred to as the expectations theory, which also plays an important role in the asset price and exchange rate channels.

10. Another facet of transmission is how interest rates in the money and capital markets influence bank deposit and loan interest rates. We can illustrate the connection between market rates and bank lending using a marginal cost pricing model, where the price set by the bank $\left(i^{B}\right)$ equals the marginal cost of funding approximated by a market interest rate $i^{M}$ and a constant markup, $\mu$ (De Bondt, 2002): 


$$
i^{B}=\mu+\beta \cdot i^{M} .
$$

11. The pass-through parameter $\beta$ is equal to 1 under perfect competition and complete information. However, full (or perfect or complete) pass-through may not prevail if markets are imperfect and information is asymmetric. In particular, the degree of pass-through crucially hinges on the presence of a unit interest rate elasticity of demand for both deposits and loans. Demand elasticities lower than one result in an incomplete pass-through $(\beta<1)$, and a combination of factors may cause the demand elasticities to become less than unity. First, imperfect substitution between bank deposits and other investment facilities of the same maturity and flexibility (money market funds, T-bills and the like), and between bank lending and other types of external finance (equity or bond markets), reduces demand elasticities: a low degree of competition between banks, and between banks and nonbank financial intermediaries, lowers the sensitivity of demand for deposits and loans to the interest rate. Second, demand elasticities may be reduced if it is costly to change banks (switching costs). In addition, market segmentation due to switching costs and a high concentration of the banking sector can lead to a monopolistic market structure, preventing the pass-through from being unity.

12. The presence of asymmetric information (adverse selection and moral hazard) may render bank lending rates less responsive to changes in the key rate. At the same time, the interest rate pass-through to lending rates can exceed one (overshooting) in the event that banks charge higher interest rates in an attempt to counteract higher risks resulting from asymmetric information, rather than reducing the supply of loans (De Bondt, 2002).

13. If competition is weak, the interest rate pass-through may vary over the interest rate cycle. When interest rates are on the rise, banks may adjust their lending rates more quickly than their deposit rates. Conversely, if interest rates are falling, they may tend to decrease their deposit rates more rapidly than their lending rates (Hannan and Berger, 1992, and Weth, 2002). Sander and Kleimeier (2004a) stress that the degree of competition is more important for the pass-through for deposit rates than for lending rates, since problems related to asymmetric information are smaller for deposit rates.

14. Furthermore, the pass-through from the policy rate to retail rates may not only be incomplete in the long run, but could be sluggish in the short run due to an array of factors: First, banks respond slowly to changes in market rates in the presence of adjustment or menu costs. They may decide to adjust lending rates less frequently than policy rates are changed, but when they do adjust, the movement is substantial. Second, the way in which banks adjust their lending rates depends on the maturity mismatch of their loan and deposit portfolio. The more long-run loans are covered by long-term deposits, the less pressure banks feel to adjust their lending rates. In other words, it matters how responsive their liability side is to market rates. Banks with extensive recourse to long-run deposits such as saving deposits, which are not particularly affected by market rates, are slower to adjust their lending rates than banks whose liability side relies more heavily on deposits or other forms of financing, which are more sensitive to market rates (Weth, 2002).

15. Third, if banks have long-term relationships with their customers, they may want to smooth interest rate changes. This may apply to universal banks and the so-called "hausbank."

16. Finally, macroeconomic conditions may also affect the pass-through. During periods of rapid economic growth, i.e. under favorable economic conditions, banks may find it easier to pass on changes in the interest rate to their lending and deposit rates more quickly. Higher inflation may also favor a more rapid interest rate pass-through, given that prices may be adjusted more frequently in a high-inflation than in a low-inflation regime. Increased uncertainty as reflected in higher interest rate volatility may, however, lower the interest rate pass-through, because banks may want to get a true picture of the underlying position. 
17. Importantly, the pass-through to loan rates is intimately related to the credit market in general and to the functioning of the credit channel in particular. As we will argue later in the paper, disequilibrium in the credit market may either diminish the completeness of the pass-through or may help in moving toward full pass-through. A related issue is how easily banks can refinance themselves. Banks which have more difficulty accessing external financing because of asymmetric information problems - usually smaller banks - increase their deposit rates to attract more deposits, and, consequently, also adjust their lending rates. By the same token, more liquid and more capitalized banks adapt their retail rates more slowly to changes in the monetary policy rate than less liquid banks with less capital (Gambacorta, 2004).

\subsubsection{Empirical Issues and Results}

18. There are three main strands in the literature relating to the choice of the explanatory interest rate variable. One strand tests how market interest rates are transmitted to retail bank interest rates of comparable maturity. This approach is termed the cost of funds approach (De Bondt, 2002). A second strand directly tests the impact on retail rates of changes in the interest rate controlled by monetary policy. Sander and Kleimeier (2004a) call this the monetary policy approach. In practice, the interest rate passthrough is usually investigated using an error correction model (ECM), including two interest rate series which may or may not include size or sign asymmetry. Size asymmetry occurs when the speed of adjustment to equilibrium depends on the size of the deviation: the higher the deviation from equilibrium the quicker the adjustment. Sign asymmetry occurs when the speed of adjustment differs depending on whether the deviation occurs above or below equilibrium or whether the policy rate declines or increases.

19. A third unifying approach includes two stages (see chart 2):

- $\quad$ the pass-through from the monetary policy rate to market rates $\left(i^{M P} \rightarrow i^{M}\right)$

- the transmission from market rates to retail rates $\left(i^{M} \rightarrow i^{B}\right)$

These two stages can be incorporated into an ECM representation as in equation (2) (Berstein and Fuentes, 2003, and De Bondt et al., 2003):

$\Delta i_{t}^{B}=\alpha_{0}+\rho\left(i_{t-1}^{B}-\mu-\beta i_{t-1}^{M}-\beta i_{t-1}^{M P}\right)+\sum_{j=0}^{l} \delta_{j} \Delta i_{t-j}^{M}+\sum_{j=0}^{l} \gamma_{j} \Delta i_{t-j}^{M P}+\sum_{j=1}^{l} \phi_{j} \Delta i_{t-j}^{B}+\varepsilon_{t}$

20. However, the interpretation of a single-equation setting becomes difficult when the series are found to be co-integrated. In this kind of setup it is probably best to test separately for the existence of two potential co-integration relationships $\left(i^{M P} \rightarrow i^{M} ; i^{M} \rightarrow i^{B}\right.$ ) using the methods of Johansen (1995).

Chart 2. The Transmission between Interest Rates

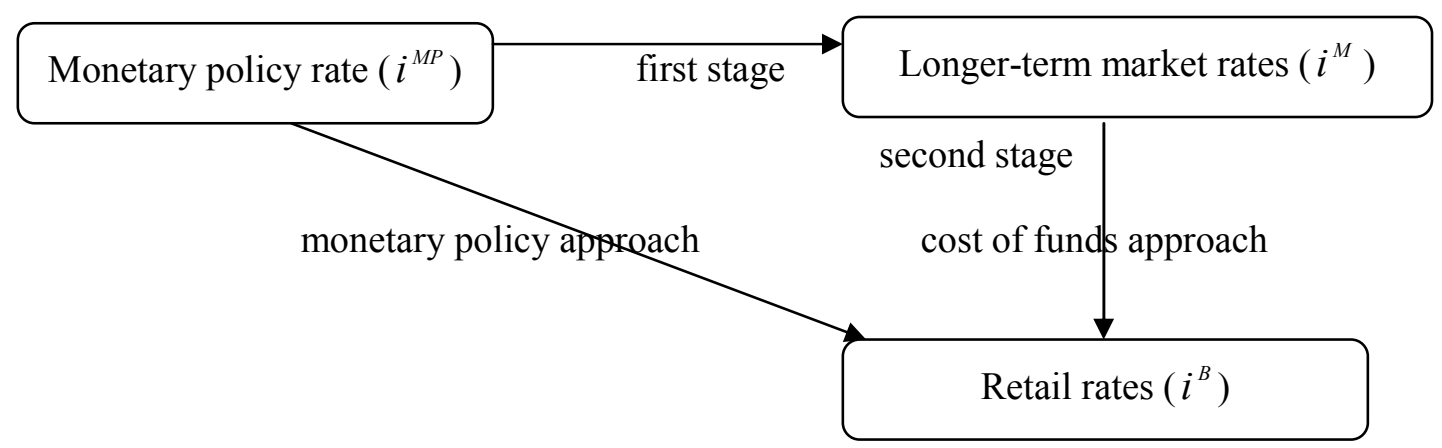


21. One difficulty with the transmission between interest rates is that the first stage relating monetary policy rates and longer-term market rates inherently measures the term structure, which crucially hinges on how expectations are formed about future inflation and the reaction of monetary policy to inflation. Consequently, the term structure may change over time and may differ between countries. For a given country, changes in the term structure may indicate changes in inflation expectations or the progress of disinflation. Across countries, differences in the term structure may stem from the heterogeneity of views about the credibility of monetary policy or of weights/preferences given to fighting inflation (the tradeoff between inflation and output stabilization).

22. Table 1 summarizes the empirical studies carried out for transition economies. ${ }^{4}$ Although the country coverage is unbalanced and the quality of the data may be of some concern in some cases, some general conclusions can be drawn. First, it appears that the pass-through from the monetary policy key rate to short-term money market rates is very high or complete. The pass-through from money market rates to market interest rates of shorter maturity also turns out to be very high, whereas the pass-through to longterm market rates is unstable mainly because of the change in the yield curve resulting from successful disinflationary policies. This implies that the pass-through from the policy rate to retail rates occurs via short-term rather than long-term market rates.

23. Most studies use the one-stage monetary policy approach to estimate the pass-through from market to retail interest rates. Three main results stand out, and they turn out to be similar to the findings for the euro area.

24. The most complete pass-through is typically found for short-term corporate lending rates followed by long-term corporate loan rates. The lowest average pass-through is observed for consumer loans.

25. The pass-through tends to be higher for the Baltic States and particularly low for the Czech Republic and Slovakia. For Hungary and Poland, the range is rather large. In general, except for Romania, the interest rate charged for new loans tends to react more strongly to market conditions than that for old loans.

26. The pass-through to deposit rates is less complete, the average long-run pass-through coefficient amounting to 0.72 for short-term deposits and to 0.69 for long-term deposits. In particular, it appears that the remuneration of current accounts and saving accounts incorporates a very low fraction of changes in market rates. However, the pass-through of time deposits increases for higher maturities.

27. Another, and perhaps surprising, observation is that there is no systematic difference between the long-run pass-through for interest rates on household and corporate deposits for Hungary and Poland. By contrast, changes in market rates are transmitted much less into corporate than into household deposit rates in Estonia and Latvia.

28. There is substantial cross-country heterogeneity for the long-run pass-through. ${ }^{5}$ Moreover, there is heterogeneity even for the same market in the same country.

4 The averages reported in the table need to be taken with a pinch of salt given that they are not fully comparable in terms of country coverage and the number of observations on which they are calculated. For the individual estimates, see the previous long version of this paper (Égert and MacDonald, 2006).

5It is not always clear whether the interest rate series used under the heading "long-run interest rates" are fixed or variable rates for long-run loans or deposits. However, the results indicate how any given composition reacts to changes in the base or market rates. 
29. Consider, for example, mortgage rates for Lithuania, where the pass-through is complete for oneyear rates and is nearly zero for five-year rates. Sander and Kleimeier (2004b) provide some quantitative support for this view by regressing the estimated pass-through coefficients on country and market dummies (for loans and deposits). The country dummies turn out to be significant. The market dummies confirm that the pass-through for short-term and long-term loan rates is higher and their reaction is swifter, especially when compared to saving and current accounts. They also find that the long-run pass-through for corporate loans is quite homogeneous, even though there are differences in the speed of adjustment. Égert, CrespoCuaresma and Reininger (2007) provide evidence of large heterogeneity across countries and market segments. They also show that a number of time series for which error correction models are estimated in the literature are not co-integrated. The regressions run for first-differenced data indicate lower passthrough coefficients.

30. A major difference between CEECs and the euro area countries is the weaker evidence in favor of asymmetry in the adjustment process. Sander and Kleimeier (2004b) conclude that the pass-through process exhibits less asymmetry in the transition economies. This statement is backed by results reported in Crespo-Cuaresma, Égert and Reininger (2004) and Chmielewski (2003). Nonetheless, Opiela (1999) finds some asymmetries for Polish bank level data from 1994 to 1998, and Horváth, Krekó and Naszódi (2004) for Hungarian deposit and loan rates for a more recent period. Égert, Crespo-Cuaresma and Reininger (2007) find an increase in asymmetry over time even though the share remains low and no clear pattern seems to emerge with regard to any specific country or interest rate series.

31. Another interesting finding on the pass-through in CEE is that both the contemporaneous and long-run pass-through increase over time, while the mean adjustment lag to full pass-through decreases, as more recent data can be used (Crespo-Cuaresma, Égert and Reininger, 2004; Horváth, Krekó and Naszódi, 2004; Sander and Kleimeier, 2004b). ${ }^{6}$ However, Égert, Crespo-Cuaresma and Reininger (2007) show that the pass-through has been slowing down in the CEE- $5^{7}$ in the past few years.

Table 1 Long-Run Interest Rate Pass-Through Estimates for the CEECs

\begin{tabular}{l|c} 
Rate & Average long-run pass-throu \\
\hline Base rate => money market r & 1.01 \\
Short-term deposit rate & 0.72 \\
Long-term deposit ate & 0.69 \\
Short-term lending rate & 1.01 \\
Long-term lending rate & 0.91 \\
Consumer lending rate & 0.51 \\
Housing/mortgage lending ra & 0.73 \\
Goverment security yields & 0.92 \\
\hline
\end{tabular}

Note: Averages are obtained using estimates reported in Árvai (1998), Crespo-Cuaresma, Égert and Reininger (2004), Horváth, Krekó and Naszódi (2004), Nickisch (2005), Sander and Kleimeier (2004b), Tieman (2004), Várhegyi (2003) and Wróbel and Pawlowska (2002).

6Világi and Vincze (1998) report very sluggish short-run adjustment and very low (0.1) long-run pass-through from 30-day and 90-day T-bill rates toward rates on new corporate loans and short-term corporate deposits for Hungary between 1991 and 1994.

The Czech Republic, Hungary, Poland, Slovakia and Slovenia. 


\subsubsection{Main Determinants of the Interest Rate Pass-Through in CEE}

32. A number of researchers have attempted to identify the factors affecting the size and speed of the pass-through. They have taken three approaches: The first consists of estimating a time series pass-through equation by including variables like market concentration (as a measure for competition). For example, Wróbel and Pawlowska (2002) show that in Poland an increase in concentration -measured by the Herfindahl-Hirschman index ${ }^{8}$ reduces the pass-through for lending rates (as expected) but increases it for deposit rates. Kot (2004) employs a different measure for competition. He argues that if competition is strong (that is, banks are price takers), the interest rate elasticity of the demand for products of individual banks $\left(\varepsilon_{i}^{I D}\right)$ is much larger than the interest rate elasticity of aggregate demand for bank products $\left(\varepsilon_{i}^{A D}\right)$. Hence, $\varepsilon_{i}^{I D}>\varepsilon_{i}^{A D}$. Conversely, if banks have market power and can therefore influence interest rates, the interest rate elasticity at the individual and at the aggregate level will be closer to one another. The empirical assessment of the elasticities shows that consumer credit markets are more competitive in Hungary and in Poland than those in the euro area and that the degree of competition is the lowest in the Czech Republic. ${ }^{9}$ A second group of papers exploits the cross-sectional dimension of the data by first estimating pass-through coefficients using time series for an array of countries and markets and then by regressing the coefficients on a number of explanatory variables, such as macroeconomic variables and variables related to the structure of the financial sector. Sander and Kleimeier (2004b) adopt this approach. Their results indicate that of the macroeconomic variables, GDP growth and financial depth do not affect the speed and the size of the pass-through, while higher inflation is associated with a more pronounced pass-through and money market volatility decreases the pass-through. ${ }^{10}$ Of the variables measuring the structural features of the financial sectors, a lower degree of concentration, fewer bad loans (a healthier banking sector) and more foreign participation tend to be associated with a higher and faster pass-through. This result holds for loans as well as for deposits.

33. The above approach can be extended to bank-level data. In such a setting, pass-through coefficients are estimated for individual banks and in the second stage are regressed on bank-specific features. Opiela (1999) uses this option and shows that for the period from 1994 to 1998, the pass-through of 37 Polish banks depends on ownership (involvement of the state), the share of bad loans and the degree of capitalization. In particular, he demonstrates that interest rates of state-owned banks respond strongly when interest rates fall; as these are banks loaded with bad loans, they pass on changes in market conditions to retail interest rates more quickly during periods of rising interest rates.

34. A third way of proceeding involves combining time series and the cross-sectional dimension of bank-level data. More precisely, the reaction of the interest rates of individual banks to monetary policy steps and how these steps interact with bank-specific characteristics are investigated in a panel setting.

35. Horváth et al. (2004) investigate whether the interest rate pass-through is heterogeneous for 25 Hungarian banks and find that the pass-through was homogeneous for corporate loan and deposit rates for the period from 2001 to 2004. Várhegyi (2003) examines the interest rate pass-through from money market rates to household deposit rates for a similar dataset (11 Hungarian banks) and sample period (2000 to

8 Alternatively, market concentration could also be measured as the share of the three or five biggest banks in terms of loans or deposits in total loans or deposits.

9 Molnár, Nagy and Horváth (2007) find that the market for personal loans is not competitive, while the market for overdaft credits is fairly competitive in Hungary when compared to theoretical benchmark models (Bertrand oligopoly and a cartel). As they do not compare markets across countries, it is difficult to say how competitive the Hungarian banking sector is compared to those in other countries.

10 This contrasts with Horváth, Krekó and Naszódi (2004), who find that higher money market volatility increases the speed of adjustment. 
2003). While the pass-through is incomplete in the long run for all banks, some heterogeneity is uncovered for individual banks.

36. Chmielewski (2003) goes a step beyond studying the pass-through at the bank level and estimates the pass-through for two groups of Polish banks as a function of whether they are good or bad in terms of (1) the share of classified loans, (2) the capital adequacy ratio, and (3) profitability captured by the return on assets. Perhaps, not surprisingly, more profitable banks adjust household deposit rates for longer maturities and for corporate loan rates faster than less profitable banks. Also, banks with more bad loans are quicker in adjusting their lending rates and slower in doing so for deposit rate. Finally, better capitalized banks turn out to react less quickly to market conditions than less capitalized banks.

37. To summarize, higher concentration of the banking sector, higher profitability and higher capitalization of banks typically make banks less receptive to adjusting their retail rates to market or policy rates, and hence dampen the interest rate pass-through. However, this general finding is in conflict with the result that the ownership structure, especially the involvement of foreigners in the banking sector, may enhance the interest rate pass-through, given that more foreign participation leads to higher concentration and that foreign-owned banks tend to be more profitable and better capitalized.

\subsection{Second Stage: The Monetary Channel}

38. While the first stage of monetary transmission concerns interest rate interactions, the second stage relates to the impact of nominal interest rate changes on the real sector. Price stickiness and rational expectations ensure that an innovation in short-term nominal interest rates will lead to moves in both shortterm and long-term real interest rates. Given that real interest rate movements reflect changes in the cost of capital and corporate investment, spending will be affected. Like investment decisions, spending on housing and durable goods is sensitive to real interest rates. Of course, changes in interest rates entail two conflicting effects. A rise in interest rates increases the income of holders of interest-bearing assets (income effect), which can be offset by higher interest rates favoring savings instead of consumption (substitution effect). Changes in investment, housing and durable goods spending, i.e. aggregate demand, will eventually cause changes in output.

39. Only a few recent empirical studies investigate this issue, in particular for CEE. The empirical evidence reported in Kátay and Wolf (2004) indicates that investment demand in Hungary is sensitive to the user cost of capital. This is evidence that the money channel is at work. ${ }^{11}$ Kiss and Vadas (2005) investigate the Hungarian mortgage market and show that changes in mortgage interest rates have only a limited influence on disposable income (income effect), mainly because of institutional factors (the government subsidy scheme and the domination of fixed noncallable mortgages).

\section{$4 \quad$ Exchange Rate Channel}

40. Beside interest rates, both nominal and real exchange rates play a prominent role in the monetary transmission mechanism. The first stage of the transmission mechanism is how monetary policy impacts on exchange rates. The second stage is then the pass-through from exchange rates to import and domestic prices, followed by an adjustment in real variables such as imports, exports and investment.

11 This finding is similar to that reported in Chatelain et al. (2001) for France, Germany, Italy and Spain. 


\subsection{Monetary Policy Actions and the Exchange Rate}

\subsubsection{Policy Rates and the Exchange Rate}

41. Central to all open economy macro models is a variant of the real interest rate parity (RIP) condition, which links the expected change in the real exchange rate to a real interest differential. ${ }^{12}$ Although the extant evidence on this relationship is rather mixed, as Baxter (1994) initially noted, it is more a reflection of the application of inappropriate econometric methods (in particular mixing I(1) and $\mathrm{I}(0)$ variables) than any inherent deficiency in the relationship itself (see also Hoffman and MacDonald, 2006).

42. Papers using the VAR methodology, surveyed in more detail later in this paper, address the impact of (monetary policy) shocks in short-term interest rates on the nominal exchange rate in transition economies and produce mixed results since positive interest rate shocks can lead to an appreciation or depreciation of the exchange rate. The latter phenomenon is usually referred to as the exchange rate puzzle, which under special circumstances can be attributed to the unsuccessful defence of a given exchange rate level.

43. Relying on a different methodological framework, Rezessy (2005) shows that for Hungary changes in the key policy rate led to systematic changes in the exchange rate and he reports the absence of an exchange rate puzzle since a rise in the policy rate causes the exchange rate to appreciate. Relying on an event study framework, Égert (2007) finds that changes in the policy rate adjusted for actual and verbal interventions are able to smooth the exchange rate, but not to reverse the appreciation trend, in the Czech Republic and Hungary and have no effect on the exchange rate in Croatia, Romania and Slovakia.

\subsubsection{Central Bank Interventions and Communication on the Foreign Exchange Market}

44. Monetary authorities may influence short-run exchange rate movements by directly intervening on the foreign exchange markets or via verbal communication. Although it is widely acknowledged that unsterilized intervention affects the exchange rate by altering relative money supply, the empirical evidence about the effectiveness of sterilized intervention, which may work through the portfolio, the signaling and the microstructure (or coordination) channels, is fairly mixed.

45. The view that foreign exchange intervention may be more effective in emerging market economies than in well established industrialized countries is gaining acceptance; the main arguments supporting this view is that in emerging markets (1) central bank interventions are not always fully sterilized, (2) the size of interventions is large relative to market turnover in narrow foreign exchange markets, (3) market organization and the regulatory framework may be more conducive to interventions, (4) moral suasion may play a bigger role, and (5) central banks have a greater informational advantage over market participants (Canales-Kriljenko, 2003).

46. Only a few papers study the effectiveness of foreign exchange intervention in transition ${ }^{13}$. Using an instrumental variable approach, Disyatat and Galati (2005) report weakly significant influence on the exchange rate in the Czech Republic between 2001 and 2002, while Égert and Komárek (2006) and Geršl and Holub (2006) report statistically significant but quantitatively not very large effects of interventions on

12 This is central to the Mundell-Fleming-Dornbusch model and also to the New Open Economy Macroeconomics (see Obstfeld and Rogoff, 1996); a risk adjusted variant of real interest rate parity is also central to the portfolio balance class of model - see, for example, Mussa (1986).

13 BIS (2005) provides a collection of foreign exchange intervention practices in the Czech Republic, Hungary, Poland and a large number of emerging market economies. 
the exchange rate using GARCH models for the period 1997 to 2002 and instrumental variable estimation for 2001 to 2003, respectively. Scalia (2006) establishes a quantitatively much stronger effect for intraday exchange rate data from July to September 2002.

47. Applying the event study approach to monthly data, Holub (2004) and Geršl and Holub (2006) find that interventions are successful in changing the exchange rate. Building on this, Égert and Komárek (2006) employ the sign bias test to establish the statistical significance of the pooled events and sheds light on the fact that actual interventions are only effective if combined with interest rate steps up to 40 days. Égert (2007) shows - within the same framework - that koruna sales can reverse an appreciation trend on their own, albeit only in the very short run, and that combining interventions with central bank communication and interest rate news is very powerful in altering the appreciation trend of the exchange rate, even up to 60 days. Égert (2007) finds this not only for the Czech Republic but also for Croatia, Hungary, Romania and Slovakia. He also finds evidence that interventions can overturn depreciation trends in Croatia, the Czech Republic and Slovakia. This suggests that appropriate central bank communication can enhance the effects of actual interventions and interest rate news. ${ }^{14}$

48. Gereben, Gyomai and Kiss (2006) estimate the effectiveness of central bank interventions in Hungary by incorporating interventions in an order flow model of the exchange rate. The estimation results indicate that interventions were successful only during the January 2003 crisis period. ${ }^{15}$

\section{Exchange Rates and Prices}

49. Nominal exchange rate movements caused by monetary policy action have the potential ${ }^{16}$ to be translated into domestic inflation on the grounds of a modification of imported final goods prices, and because an alteration in the price of imported intermediate goods puts downward or upward pressure on domestic inflation via the price of domestically manufactured tradable and nontradable goods.

50. How the exchange rate affects domestic prices via imported prices in the end depends crucially on the pricing behavior of importing firms. If prices are set in the importer's currency (producer currency pricing - PCP), any change in the exchange rate will be automatically transmitted to the prices of the destination country. This implies complete exchange rate pass-through, which is sometimes also referred to as Grassman's law, and the validity of the law of one price, since the real exchange rate remains stable. ${ }^{17}$

14 See Blinder et al (2008) for more details on central bank communication.

15 Two interesting questions arise here. First, what are the channels of this success. In Croatia, where interventions are announced in advance, the signaling channel may play a role on top of the portfolio channel and the microstructure (order-flow) channel. However, for the other countries with secret discretionary interventions, only the two latter channels can play a role. Second, to what extent is this success due to unsterilized interventions. Égert (2007) argues that most central banks in Central and Eastern Europe, perhaps with the exception of Croatia, tend to fully sterilize FX interventions. But the only partial sterilization in Croatia does not lead to a substantial improvement of the effectiveness of FX interventions as compared to the other countries. An explanation for this is that the monetary model, which ensures that unsterilized interventions are transmitted to the exchange rate, is not operational in Croatia (see Crespo-Cuaresma, Fidrmuc and Silgoner, 2005). This makes us cautious about the generally accepted view that unsterilized interventions automatically influence the exchange rate.

16 The word potential has to be underlined here, as a great deal of factors aside from monetary policy have the ability to cause the exchange rate to change. As a result, the pass-through of the exchange rate to prices is only partly due to monetary policy action.

17 Another implication is that a change in the relative price of imported and domestic goods will shift consumption from one type of good to the other (expenditure switching). 
51. Alternatively, if the price of imported goods is fixed in the local currency (local or consumer currency pricing - LCP), exchange rate movements are not reflected in domestic prices and the passthrough is zero. As a consequence, the real exchange rate may drift away from the level given by the law of one price and is correlated with the nominal exchange rate. ${ }^{18}$ Importing firms practicing LCP will alter their markup in response to changes in the exchange rate, while those engaging in PCP usually adjust their output and labor in response to changes in local prices.

\subsubsection{Differing Pass-Through for Imported, Producer and Consumer Prices}

52. A typical finding of the empirical literature for imported goods prices in industrialized countries is that the pass-through lies between 0 and 1, which disqualifies both LCP and PCP (Campa and Goldberg, 2002). ${ }^{19}$ The incomplete pass-through to import prices may be due to third-degree price discrimination, eventually preventing a complete pass-through even for homogeneous imported goods.

53. However, even if we assume perfect pass-through for imported goods, the large body of literature dealing with the exchange rate pass-through usually pins down the following hierarchy across prices: The pass-through is highest for imported goods, is lower for producer goods and is lowest for consumer prices. Although this is not surprising at first glance for purely domestically produced goods and services (without any imported intermediate input), there are two ways of looking at the pass-though result:

54. One strand of the literature emphasizes the role of distribution costs for final imported goods. As imported goods reach consumers through wholesaling and retailing networks (including transportation, marketing and advertisement), their prices have a substantial local input, which serves as a buffer to soften the impact of exchange rate changes. Burstein, Eichenbaum and Rebelo $(2002,2004)$, for example, show that large devaluations of the home currency are not reflected in inflation of corresponding size because of the distribution sector and because consumers switch from imported goods to lower-quality - and hence cheaper - local brands (flight from quality). Analogously, large appreciations may not necessarily yield lower inflation if there is a flight to quality.

55. Other researchers emphasize the role of intermediate imported goods by assuming that imported goods are intermediate goods to which PCP applies (that is, the pass-through is complete). The price of final goods, which is a combination of the price of imported intermediate goods and of local goods, is set in local currency (Engel, 2002). ${ }^{20}$ The pass-through would be higher than zero but sluggish in the event that prices in local currency are adjusted periodically (due to sticky prices) when exchange rate movements could also be incorporated.

\subsubsection{A Slowdown of the Pass-Through to Prices Over Time}

56. Another important finding in the literature is that the exchange rate pass-through is higher for developing countries and that it declines over time both for industrialized and for developing countries. ${ }^{21}$ Two explanations are advanced for this observation in the literature. The first one relates to the role of macroeconomic variables, especially inflation. The second option considers the shift in imports from goods with higher pass-through elasticities to goods with lower ones.

18 This is indeed a well documented fact for industrialized countries (see MacDonald, 2005).

19 Choudhry et al. (2005) find that the theoretical model that best fits the data is the one that incorporates sticky prices and wages, distribution costs and a combination of LCP and PCP.

20 In this sense, there is expenditure switching for the producer and not for the consumer.

21 Campa and Goldberg (2002) argue that the decline in the exchange rate pass-through can be observed only for half of the OECD countries. 
57. The role of the macroeconomic environment. Taylor (2000) conjectured that the slowdown in the pass-through (and the difference between developing and industrialized countries) is due to changes in the macroeconomic environment, in particular in the level and variability of inflation rates. This proposition has been extensively tested in a two-stage approach similar to that used for the investigation of the determinants of the interest rate pass-through. 22 Devereux and Yetman (2003), Choudhri and Hakura (2001) and Ca'Zorzi, Hahn and Sanchez (2007) rely on a two-stage approach for a large number of countries to show that that high inflation is conducive to perfect pass-through and is often associated with complete pass-through. Bailliu and Fujii (2004) use a panel setting in which changes in inflation rates are controlled for by means of dummy variables. In contrast to the earlier literature, it turns out that the passthrough declined for import, producer and consumer prices for a set of 11 OECD countries during the 1990s. Gagnon and Ihrig (2001), and especially Soto and Selaive (2003), claim that inflation variability is more important than the level of the inflation. In addition, Soto and Selaive (2003) also find openness and country size to be important factors in determining the pass-through. The higher the openness and the smaller a country is ${ }^{23}$ they argue, the higher the pass-through is.

58. The composition of trade and imports. Even though Campa and Goldberg (2002) confirm the importance of inflation, and of exchange rate volatility, ${ }^{24}$ they emphasize that the macroeconomic factors are dominated in the long run by what they call the "composition effect." As the pass-through is nearly complete for energy and raw materials and is considerably lower than unity for food and manufactured products, a shift in the composition of imports from raw materials to manufactured goods, the argument goes, induces a decline in the exchange rate pass-through for imported goods. The econometric tests support this idea for a sample of OECD countries. This kind of reasoning could be applied to explain why the pass-through is higher for developing countries (which import more high pass-through goods) than for developed countries (which import more low-pass-through goods).

59. Evidence based on individual imported goods. Frankel, Parsley and Wei (2005) study the passthrough to prices of individual goods ${ }^{25}$ for a large set of countries. In general, it turns out that the passthrough is not complete for import prices at the dock. Also, the pass-through to import prices in the U.S.A. is found to be considerably lower than in other developed economies. Given the high disaggregation of the data, the composition effect cannot be at the root of this phenomenon, which detracts from the Campa and Goldberg argument. However, they also find that the pass-through to import prices increased over time while it decreased for the retail and CPI level for developing countries (but not for developed ones).

60. The role of the monetary policy regime. The pass-through is thought to be higher for countries where the exchange rate serves as a nominal anchor to inflationary expectations. In these countries, any change in the exchange rate will be rapidly incorporated into expectations and thus into prices (both tradable and nontradable). In contrast, if the exchange rate is not used as an intermediary target, expectations are not that strongly associated with the exchange rate, resulting in a lower pass-through. In a floating regime, exchange rate changes will have little influence on non-tradable prices. For instance, Edwards (2006) shows that the exchange rate pass-through declines after the introduction of inflation targeting regimes that shifts inflation expectations from the exchange rate to the inflation target. As a

22 First, country-specific exchange rate pass-through coefficients are estimated. Second, the estimated coefficients are regressed on a number of candidate explanatory variables.

23 They measure openness in three alternative ways: (1) imports to GDP, (2) import duties as a share of imports, and (3) tariff rates on intermediate and capital goods.

24 Note that Soto and Selaive (2003) cannot find evidence, for a larger sample, of exchange rate volatility as a driving force behind exchange rate pass-through.

25 Marlboro cigarettes, Coca-Cola, cognac, Gilbey’s gin, Time magazine, Kodak color film, Cointreau liqueur and Martini \& Rossi vermouth. 
matter of fact, one measure of success of inflation targeting is the decline in the exchange rate pass-through (Schmidt-Hebbel and Werner, 2002).

\subsection{Exchange Rate Pass-Through in Transition Economies}

61. A common practice in the literature is to estimate the exchange rate pass-through either relying on (recursive) VAR models devised by McCarthy (1999) or using a single equation approach that incorporates differenced variables (Campa and Goldberg, 2002) or that employs single equations in which the deviation from the long-run equilibrium exchange rate is modeled (Frankel, Parsley and Wei, 2005). Evidently, the exchange rate pass-through is intimately related to equilibrium exchange rates and to real misalignments. Both the VAR approach and the single-equation approach largely ignore this issue, which may mean that there is an omitted variable bias which could have serious implications for the estimated pass-through. For industrialized countries, this means that large nonequilibrium deviations from PPP should be accounted for when analyzing the exchange rate pass-through (Frankel, Parsley and Wei, 2005). The issue is possibly even more important for transition countries because their equilibrium exchange rates exhibit large changes, in particular a strong trend appreciation during the phase of economic transformation. ${ }^{26}$ Hence, the trending movement of the equilibrium exchange rate and the deviation of the real exchange rate from this trend should be clearly considered for the study of the pass-through. Darvas (2001) stands out from the rest of the literature in that it models the equilibrium exchange rate and the degree of exchange rate pass-through jointly. In particular, the author first estimates the equilibrium exchange rate using the single-equation Behavioral Equilibrium Exchange Rate (BEER) approach. Next, prices and the nominal exchange rate are estimated using the following system:

$$
\begin{aligned}
& \Delta p_{t}=\alpha+\beta \Delta e_{t}+\chi \Delta p_{t}^{*}+\delta\left(q_{t-1}-q_{t-1}^{E Q}\right)+\varepsilon_{t} \\
& \Delta e_{t}=\gamma+\eta\left(q_{t-1}-q_{t-1}^{E Q}\right)+\varepsilon_{t}
\end{aligned}
$$

where $\left(q_{t-1}-q_{t-1}^{E Q}\right)$ measures the misalignment of the real exchange rate. In this setting, $\beta$ represents the instantaneous long-run pass-through. Moreover, Darvas (2001) allows for time-varying parameters in his specification, given that the pass-through may (and, according to his results, does) change over time.

62. Another important issue to mention here is that the exchange rate pass-through may depend on the source that generates changes in the exchange rate. For instance, a change brought about by monetary policy may be transmitted differently to prices than exchange rate movements generated by other exogenous factors. This issue is not addressed in the empirical literature. ${ }^{27}$

63. Notwithstanding the substantial shortcomings on the estimation side, ${ }^{28}$ the average exchange rate pass-through reported in the row "average" of table 2 reveals the incomplete nature of the pass-through from the exchange rate to prices, not only in the short run but also at a longer horizon. Table 2 also shows the term structure of the pass-through, which turns out to be highest for import prices with an average passthrough of $62 \%$. A $1 \%$ change in the exchange rate results in an average $0.52 \%$ change in producer prices. Finally, as expected, the overall impact is the lowest on the CPI.

26 For an overview of this issue, see e.g. Égert, Halpern and MacDonald (2006).

27 We thank an anonymous referee for pointing this out.

28 Another cautionary note is in order: some authors use sample periods going well before economic transition started in 1990. Campa and Goldberg (2002), Choudhri and Hakura (2001) and Soto and Selaive (2003) employ data going back to the 1970s, while the sample period starts in 1988 for Hungary in Ca'Zorzi, Hahn and Sanchez (2005). In addition, the definition of changes in the exchange rate is not the same across studies. Some analyse the impact of shocks while others look at simple changes in the exchange rate. 
64. A first obvious specific observation is the large heterogeneity across countries regarding the passthrough to the CPI. CPI inflation is less affected by the exchange rate in the Czech Republic and is highest in Slovenia (53\%) and Bulgaria (68\%). The pass-through is also below the sample average for Romania (for the U.S. dollar).

65. In addition, two tentative observations can be made. The pass-through to the CPI tends to be higher for countries at a lower stage of development (Korhonen and Wachtel, 2005). Also, we can observe a larger pass-through for countries with an accommodative monetary policy at some stage (Slovenia and Romania). If a country operates an officially announced or unofficial crawling peg exchange rate regime, the preannounced devaluation of the currency provides a nominal anchor for expectations. As changes in the exchange rate may signal changes in prices, changes in the exchange rate will generate corresponding changes in prices not only for tradables but also for nontradables via the expectation channel. This would imply a high and quite homogeneous pass-through for the whole CPI. The move toward more exchange rate flexibility, coupled with an inflation targeting framework, may break the link between the exchange rate and prices by disconnecting primarily nontradables from the exchange rate (Coricelli, Jacbec and Masten, 2003; Darvas, 2001; Kara et al., 2005).

66. However, studies focusing on one country sometimes strongly disagree regarding the size of the pass-through. One prominent example is Estonia: while Dabušinskas (2003) finds a zero pass-through to the $\mathrm{CPI},{ }^{29}$ Bitans (2004) reports an average pass-through of $53 \%$.

67. Second, for the Russian case Dobrynskaya and Levando (2005) identify a higher pass-through to food and goods prices (around 50\% and 30\% in the long run) and virtually no pass-through to services. The finding for food is broadly in line with Dabušinskas (2003) for Estonia. However, somewhat oddly, there is no pass-through for goods in the Estonian CPI.

68. Mihaljek and Klau (2001) claim that using a measure of CPI gleaned from nonmarket prices, such as administered and regulated prices, increases the long-run pass-through. Comparing their estimates for the Czech Republic, Hungary and Poland with the rest of the sample verifies this assumption. Along these lines, it turns out that the pass-through is biased downward by roughly $10 \%$ for Latvia when the price measure includes nonmarket prices (Bitans, 2004).

69. The exchange rate pass-through is found to be higher for the producer price index (PPI) than for the CPI for all countries except Croatia and Russia. Even for the Czech Republic, which has the lowest pass-through to the CPI, roughly $40 \%$ of exchange rate changes are passed on to producer prices. For the remaining countries, the pass-through to the PPI is usually above $50 \%$. It is also more convenient to take the market-based component of the PPI. While no pass-through could be found on the basis of the overall PPI for Estonia, the PPI for manufacturing (net e.g. of energy, mining prices) reflects a large amount of changes in the effective exchange rate. Overall, the producer prices of manufactured goods, in particular machinery and equipment, are more receptive to changes in the exchange rate than other items are.

70. The pass-through to the price of imported goods is nearly complete in Estonia, Hungary and Poland and is complete in Slovakia, while it is below the pass-through to the PPI for Latvia, Lithuania and Slovenia. Although a similar degree of heterogeneity can be found for subgroups of imported goods, the pass-through is highest in machinery, followed by other manufactured and chemical goods.

71. Third, the pass-through appears to be larger against the anchor or reference currency. ${ }^{30}$ This point is clearly demonstrated for Romania (Gueorguiev, 2003; Korhonen and Wachtel, 2005), where the pass-

29 Given that the nominal exchange rate is fixed vis-à-vis the euro in the currency board arrangement, the pass-through measures how changes in the nominal effective exchange rate are translated into inflation. 
through is about twice as large against the dollar as against the euro. Inversely, changes in the dollar exchange rate matter little for prices in the Czech Republic and Hungary, for instance.

72. Finally, and overall, although the pass-through may have increased up to the mid- or late 1990s (Campa and Goldberg, 2002), it seems to have been falling since then, as convincingly evidenced by Bitans (2004), who argues that this finding is closely related to the decline in inflation rates. An interesting finding is that the pass-through for manufactured goods tends to be higher than for raw materials both for import and for producer prices (Rodzko, 2004). This could invalidate the composition effect put forth by Campa and Goldberg (2002). ${ }^{31}$

Table 2 Summary of the Exchange Rate Pass-Through in Transition Economies

\begin{tabular}{|c|c|c|c|c|c|c|}
\hline & \multicolumn{2}{|c|}{$\begin{array}{l}\text { Import Prices } \\
\text { short-ru long-rr }\end{array}$} & \multicolumn{2}{|c|}{$\begin{array}{l}\text { PPI } \\
\text { short-ru long-ru }\end{array}$} & \multicolumn{2}{|c|}{\begin{tabular}{|l|} 
CPI \\
short-ru long-rr \\
\end{tabular}} \\
\hline \multicolumn{7}{|c|}{ Average of the sample } \\
\hline Average & 0.44 & 0.7 & 0.16 & 0.52 & 0.31 & 0.33 \\
\hline \multicolumn{7}{|c|}{ Country-specific averages } \\
\hline \multicolumn{7}{|c|}{ CEE-5 } \\
\hline Czech Republic & 0.34 & 0.65 & -- & 0.41 & 0.10 & 0.23 \\
\hline Hungary & 0.58 & 0.87 & -- & 0.57 & 0.38 & 0.30 \\
\hline Poland & 0.57 & 0.84 & -- & 0.6 & -- & 0.31 \\
\hline Slovakia & 0.41 & 1.01 & -- & 0.73 & -- & 0.35 \\
\hline Slovenia & 0.26 & 0.40 & -- & 0.78 & 0.20 & 0.53 \\
\hline \multicolumn{7}{|c|}{ Baltic Three } \\
\hline Estonia & 0.59 & 0.83 & -- & 0.47 & 0.00 & 0.35 \\
\hline Latvi & 0.43 & 0.45 & -- & 0.66 & -- & 0.39 \\
\hline Lithuania & 0.22 & 0.32 & -- & 0.55 & 0.07 & 0.32 \\
\hline \multicolumn{7}{|c|}{ SEE } \\
\hline Bulgaria & -- & -- & -- & 0.94 & -- & 0.68 \\
\hline Croatia & -- & -- & -- & 0.17 & -- & 0.22 \\
\hline Romania (EFF/EUR) & -- & -- & 0.22 & 0.48 & 0.06 & 0.21 \\
\hline Romania (USD) & -- & -- & 0.23 & 0.53 & 0.28 & 0.42 \\
\hline \multicolumn{7}{|c|}{ CIS } \\
\hline Russia & -- & -- & 0.11 & 0.23 & 0.42 & 0.40 \\
\hline Ukraine & -- & -- & -- & -- & -- & 0.44 \\
\hline
\end{tabular}

Sources: Égert and MacDonald (2006) report the individual studies based on which the averages are obtained.

Note: The averages are based on nonnegative pass-through estimates. Negative pass-through estimates were set to zero. The average of country specific averages does not equal the figure given in the row "Average," as the sample specific average is obtained as the average of all available pass-through estimates. EFF, EUR and USD indicate the pass-through from the effective exchange rate and from the euro and dollar exchange rates, respectively.

\subsection{The Impact of the Exchange Rate on Trade and Investment}

73. As regards trade flows, an appreciation (depreciation) of the exchange rate is thought to penalize (promote) exports and increase (decrease) imports, leading to a deteriorating (improving) trade balance. However, this holds true only if the Marshall-Lerner condition is verified and the sum of the price

30 The reference currency in the case of floating would mean the currency in which most real and financial contracts are denominated.

31 A criticism of the above work lies in its failure to address possible asymmetries in the pass-through. The pass-through could be different depending on whether the exchange rate depreciates, appreciates or does neither, whether changes in the exchange rate exceed a certain threshold (are large enough) or how much the exchange rate deviates from its equilibrium level. The exploration of these issues awaits future research. 
elasticities of export and import demand is higher than unity. The functioning of the Marshall-Lerner condition is also based on full pass-through to import prices (in local currency) and zero pass-through to export prices (in foreign currency). Hence, the failure of complete pass-through implies that the MarshallLerner condition need not apply.

74. Burstein, Neves and Rebelo (2004) document the fact that the import content of investment is significantly higher than the import content of consumption. As a result, the pass-through to investment prices is potentially higher than that to the price of consumer goods. However, the pass-through is also incomplete because of the nontradable component of investment. The bulk of the nontradable component in investment is due to construction services while the share of distribution services is negligible.

75. Campa and Goldberg (1995) postulate that the impact of the exchange rate on sectoral investment depends on the export share and the import content of production of the sector. More specifically, exchange rate depreciation (appreciation) expands (decreases) investment if the export share is high. A high import content of sectoral production works in the opposite direction. Furthermore, high markup sectors tend not to respond to exchange rate movements in investment demand, whereas low markup sectors respond more strongly to changes in the exchange rate.

76. We can draw a connection here between the exchange rate channel and the credit channel. The effect of the credit channel (see below) on the economic activity of firms constrained by external finance is exacerbated if these firms are in low markup sectors. The second relation linking the exchange rate channel and the credit channel is the influence of exchange rate movements on foreign currency-denominated assets and liabilities in firms' balance sheet and thus their net wealth. If changes in the exchange rate impact significantly on firms' balance sheet, they will influence these firms' capacity to borrow externally (broad lending channel). A collapse in investment due to an exchange rate-induced fall in firms' net wealth may outweigh competitiveness gains, provided the Marshall-Lerner condition is verified (Carranza, Galdón-Sánchez and Gómez-Biscarri, 2004).

77. It is worth mentioning that not only the level but also the variability of the exchange rate is an important factor for trade and investment. Although the relationship between exchange rate volatility and aggregate or bilateral export flows seems to be ambiguous for developed countries, differentiating between sectors suggests a negative relationship between exchange rate volatility and export flows. Hence, the higher the exchange rate volatility is, the more trade is penalized, and consequently the more investment is affected. Nonetheless, the impact of volatility differs both in magnitude and direction across sectors. For developing countries, the literature unanimously supports the hypothesis that exchange rate volatility has a negative effect on exports flows (for an overview, see e.g. McKenzie, 1999).

78. Égert and Morales-Zumaquero (2008) studied the influence of exchange rate volatility on exports for a number of CEE countries. On the basis of standard export equations, augmented with foreign direct investment (FDI), the panel estimations indicate that a rise in foreign exchange volatility, measured either directly or via changes in the exchange rate regime, hinders exports and that this negative impact is transmitted with some delay rather than instantaneously. It turns out that the sectors which account for up to $80 \%$ of exports, such as chemicals and different types of manufacturing, suffer most from increased exchange rate volatility. Nevertheless, country-specific time series estimations reveal a great deal of heterogeneity across countries. For instance, there is little or weak evidence in favor of a negative relation between foreign exchange volatility and exports in Slovenia, Russia and Romania, while for Croatia, the Czech Republic, Hungary and Poland, the estimation results provide reasonably robust evidence on the detrimental effect of foreign exchange volatility on exports. 
79. According to Bernanke and Blinder (1988), the traditional interest rate channel performs poorly, as changes in the long-term real interest rate, i.e. the cost of capital, appear to be only weakly related to changes in global demand and thus fail to explain the amplification effect of short-term interest rates on output. Given this, they extend the transmission mechanism by introducing the credit channel, which, they argue, is an enhancement channel that amplifies the interest rate channel. The credit channel can be decomposed into two distinct channels: (1) the bank lending channel and (2) the broad lending channel (also termed balance sheet channel or financial accelerator), which are dealt with below. ${ }^{32}$

\subsection{The Bank Lending Channel}

80. The bank lending channel can be formally modeled by introducing credit into the product markets in the traditional IS-LM setup (Bernanke and Blinder, 1988), where the IS curve is replaced by the credit-commodity (CC) curve to produce the CC-LM model. Central to the bank lending channel is the imperfect substitutability between credits and other financial assets in the banks' balance sheet on the one hand, and that between bank credits and other forms of financing on firms' balance sheet on the other hand. These two forms of imperfect substitutability cause monetary policy to impact on economic activity in two stages.

81. Imperfect substitution in banks' assets ensures that a tightening (loosening) of monetary policy brings about a contraction (expansion) in banks' credit supply (the first stage). When facing a decrease in liquidity, ${ }^{33}$ banks decrease their credit supply instead of selling bonds they possess because they have the desired level of liquidity to face, for instance, unexpected deposit withdrawals. Alternatively, banks could also issue bonds or collect deposits from households or from the corporate sector rather than decrease credit. However, the ability of some banks to borrow from financial markets may be limited by financial market imperfections, such as adverse selection and moral hazard (imperfect substitutability between credits and bonds on the asset side and bonds and deposits on the liability side).

82. For monetary policy to be transmitted to the real economy, it is necessary for some firms not to be capable of substituting bank credit for other forms of external funding on the capital markets (imperfect substitutability on the liability side of firms). ${ }^{34}$ In such a case, once credit supply has decreased (increased), investment spending will be cut back because of the lack of external financial resources (second stage).

83. Underlying the analysis of Bernanke and Blinder are the hypotheses that (1) the income elasticities of credit demand and money demand are the same, and (2) the interest elasticity of credit

32 A detailed overview of the theoretical and empirical literature related to the bank lending channel can be found in Kierzenkowski (2004).

33 Bernanke and Blinder assume that the central bank controls base money, and that a tightening (loosening) of monetary policy decreases (increases) the liquidity of the banking sector. Alternatively, it is also possible to model monetary policy, which controls the interest rate. A simple way is to assume the stability of money demand functions, through which a change in the interest rate affects monetary aggregates. A more elaborate way is to introduce some kind of monetary policy reaction function, which links the policy rate to other variables.

34 Central to this analysis is the special role banks play in the presence of asymmetric information, which has been widely acknowledged since the seminal articles of Akerlof (1970) and Fama (1985). In addition to reducing transaction costs (the cost of searching, verifying and monitoring costs) and transforming maturity, banks are in a good position to reduce problems related to asymmetric information (adverse selection and moral hazard), i.e. transforming risk. For a recent general overview on market imperfections, see DeGennaro (2005). 
demand equals that of credit supply. Kierzenkowski (2005a, 2005b) has recently shown that relaxing, in particular, hypothesis (2) implies that the bank lending channel need not automatically lead to an amplification in this framework and can, importantly, also cause attenuation.

\subsection{The Broad Lending Channel ${ }^{35}$}

84. Imperfect substitution in banks' assets and in firms' liabilities, the cornerstone of the BernankeBlinder model, is not necessarily the case. In accordance with Kashyap, Stein and Wilcox (1993), while small banks cannot borrow on financial markets, larger banks definitely can. Similarly, larger firms have access to capital markets and can escape bank credit supply contraction. This leads us to a larger concept, namely to the broad lending channel. Imperfect substitution no longer exists between bank credits and other financing but between external and internal financing, ${ }^{36}$ where the cost of external financing is higher with the external financing premium. The external financing premium, in turn, primarily depends on net wealth ${ }^{37}$ serving as collateral for loans and credits. The higher the net wealth of the borrower is, the lower the external risk premium is mainly because (1) higher (expected future) revenues enable one to finance investment internally, and (2) more valuable collateral increases the safety of the lender, thus decreasing both moral hazard and adverse selection. Consequently, any change in net wealth generated directly or indirectly by monetary policy will be reflected in the risk premium and thus in the capacity to borrow. Monetary policy can influence net wealth via the interest rate, asset price and exchange rate channels described earlier:

85. Income effect (or cash-flow channel): An increase (decrease) in short term interest rates increases (decreases) the cost of servicing short-term and floating-rate debt, which reduces (raises) cash flow and thus net wealth.

86. Debt channel: An unexpected rise in inflation makes the real costs of servicing the debt lower, the terms of which are determined in nominal terms.

87. Asset price channel 1: An increase (decrease) in short-term interest rates lowers (increases) the price of equity, bonds and housing, which thus directly influences net wealth.

88. Asset price channel 2 (wealth and liquidity effect of households): monetary policy can impact on household borrowing capacity, as described in the asset price channel. ${ }^{38}$

89. Exchange rate channel: If assets or credits/loans are denominated in foreign currency, nominal exchange rate developments can increase (decrease) their value in domestic currency, which also exerts an influence on borrowing capacity.

35 This channel is also termed financial accelerator, balance sheet channel or borrower net worth channel.

36 This contrasts with the Modigliani and Miller theorem on the neutrality of internal and external funding. Note that in the broad lending channel, banks no longer play a special role, like they do in the bank lending channel.

37 Net worth or net assets are obtained as total assets minus total liabilities.

38 It is noteworthy that both the bank lending channel and the broad lending channel apply not only to the investment of the nonfinancial corporate sector but also to household spending. On the one hand, a fall in credit supply related to consumption or housing reduces credit to households, which are particularly bank dependent. On the other hand, a decrease in the price of assets (bonds and equities) and housing held by households and a fall in income reduces the value of households' collateral for loans. 
90. Second-round effects: If household or firm spending falls as a consequence of monetary policy action, other firms' revenue also falls, leading to a decrease in net wealth as a function of rigidities on the cost side.

91. Therefore, decreasing (increasing) net wealth by lowering both equity and housing prices and cash flow (income effect) results in a decreased (improved) capacity to obtain loans because of the aforementioned imperfections of financial markets (adverse selection and moral hazard), which provoke a decrease (increase) in investment and consumption spending.

92. It is worth mentioning that the broad lending channel conveys not only the effects of monetary policy, not simply because of changes in monetary conditions but also because alterations of other exogenous factors may lead to changes in the balance sheet of both households and nonfinancial corporations.

\subsection{The Trade Credit and the Bank Lending Channel}

93. Trade credit, which is usually created if a firm delays payment to its supplier, is thought to be more expensive than bank credit. However, this holds true only during "normal" times. Because the terms of trade credit are fairly stable over time, trade credit may become cheaper relative to bank credit in the wake of a monetary policy tightening. In fact, trade credit may become the only external source of financing for firms which have no credit rating and thus no access to capital markets during credit rationing. As a result, if firms also have access to trade credit, instead of only bank and market financing, firms hit by external financing constraints in the wake of monetary tightening can potentially avoid the squeeze by increasing trade credit (see Mateut, 2004). ${ }^{39}$

\subsection{The Bank Capital Channel}

94. A number of recent papers put strong emphasis on the prominent role bank equity capital plays in the monetary transmission mechanism - also called the bank capital channel - through which monetary policy influences credit supply. The standard credit channel literature has been criticized because it assumes that the central bank affects loan supply by altering the required reserves. Chmielewski (2005) stresses that reserve requirements may be inappropriate, as, for instance, inflation-targeting central banks which use the interest rate as their main policy instrument may not be able to control required reserves. Yet changes in bank capital requirements may strongly affect loan supply. The bank capital channel has been formalized, for instance, by Van den Heuvel (2002). For the bank capital channel to be operational, the following assumptions need to apply: (1) it is costly for banks to raise equity, (2) banks assume an interest rate risk, with the maturity of their credit being higher than that of their deposits, and (3) capital regulations influence banks' credit supply.

95. The mechanism works as follows. A rise in interest rates triggered by monetary policy action increases the cost of financing (deposits) while leaving the remuneration of bank assets unchanged due to the maturity mismatch. This induces a fall in bank capital. In the event that the bank is close to the minimum capital requirement prescribed by law, it is obliged to decrease the supply of loans, as raising equity is costly.

39 Trade credit amounts to up to a quarter of firms' liabilities in the U.S.A., Germany, France and Italy (Mateut, Bougheas and Mizen, 2003) and is considerably higher in the U.K. (Kohler, Britton and Yates, 2000).

40 Although the literature typically views the bank capital channel as a separate channel from the credit channel, for the sake of convenience, we put it in the same basket, because its implications are very close to those of the credit channel. 
96. According to Van den Heuvel (2002), banks with low capital react slowly but then in an amplified fashion to monetary policy shocks. Even banks with high capital can adjust their loan portfolio if they expect trouble in meeting capital requirements in the future or, as emphasized by Chmielewski (2005), they intend to maintain the same level of riskiness of their loan portfolio.

97. In a banking system where banks possess a considerable amount of corporate equity, like in Germany, any change to the price of corporate equity will have a direct impact on banks' profit, capital and consequently on their credit supply (Markovic, 2004).

98. Markovic (2004) distinguishes between three subchannels of the bank capital channel:

- The default risk channel. This channel is related to the eventuality that the bank defaults on its equity, which, in turn, depends on the default risk of firms.

- The adjustment cost channel. This channel reflects asymmetric information between the bank and its shareholders and the fact that the elimination of this asymmetry is costly.

- The capital loss channel.

99. Markovic (2004) argues that the capital cost channel is likely to gain importance in the occurrence of large shocks to bank capital, such as the write-off of nonperforming loans or changes in the regulatory framework.

\subsection{Trojan Horses Affecting the Credit Channel}

100. There are a number of potential sources which could counteract the transmission mechanism of the bank lending channel in its first and second stages and the internal-external financing constraint crucial for the broad lending channel.

\subsubsection{Factors Interfering with the First Stage of the Bank Lending Channel}

101. Multibank holding networks are conducive to the creation of internal capital markets from which affiliated banks can benefit even though external financing resources have dried up. This is especially important for small banks, as, contrary to the basic assumption of the Bernanke and Blinder model, they can insulate their loan supply from monetary policy shocks (Ashcraft, 2005). This implies that a smaller number of banks are subject to imperfect substitutability on the asset side. In extreme cases where most banks belong to banking networks, as is the case in Germany or in Finland, the bank lending channel might be completely disabled. Ehrmann and Worms (2004) argue that in such cases, the existence of the bank lending channel depends on the financial situation of the network and not on the financial health of the individual banks. Gambacorta (2005) also shed light on the network effect for Italian banks.

102. A banking system which is well capitalized overall may be less conductive for the bank capital channel.

103. A high degree of concentration of the banking sector implies the absence of small banks. As large banks have easier access to alternative external financing, they can buffer their credit supply from monetary policy shocks (Adams and Amel, 2005).

104. There is crucial interaction between the credit channel and the interest rate pass-through. It appears that more concentrated markets are less vulnerable to the credit channel. At the same time, banks on these markets do not tend to react proportionately to interest rate changes. Hence, they cushion the 
effect of monetary policy not only for quantities but also for prices, and this weakens the overall impact of monetary policy on the real economy.

105. The maturity structure of loans and the tradeoff between fixed or variable interest rates can very much determine the reaction of loan supply to monetary policy actions. The shorter the maturity structure, the more immediate the pass-through from monetary policy to loan supply is supposed to be (Ehrmann et al., 2001).

106. Relationship lending, i.e. the phenomenon of the hausbank, may lead to loan commitments, which could help disconnect loan supply from monetary policy to some extent (Ehrmann et al., 2001).

107. The government's involvement in the banking sector either as an owner or via public guarantees can partially offset the effects of monetary policy on loan supply (Ehrmann et al., 2001).

108. If loans to the private sector are denominated in foreign currency, domestic interest movements have only a limited effect on the supply of and demand for loans, since their price is given by the foreign interest rate plus the exchange rate premium. ${ }^{41} \mathrm{~A}$ contracting monetary policy manifesting itself in higher interest rates would have an opposite effect than desired, as it would cause an appreciation of the exchange rate, which, in turn, would lead to a shrinkage of the foreign currency-denominated loan in domestic currency terms. The higher the share of foreign currency-denominated loans in total lending is, the lower the direct impact of domestic monetary policy on domestic lending and borrowing activity is.

\subsubsection{Factors Interfering with the Second Stage of the Bank Lending Channel}

109. A number of other factors in addition to trade credit and other sorts of intercompany loans can potentially break down the second stage of the bank lending channel:

110. A potential attenuation of both the bank lending and the broad lending channel can occur if firms are able to insulate themselves from short-term shocks in bank or external borrowing via altering capacity utilization, if financial constraints are anticipated in advance (Wang, 2001).

111. Government involvement may also mean soft budget constraints for firms (Kornai, Maskin and Roland, 2003). This issue may be especially important for transition economies, where the hardening of the budget constraint may vary as a function of how advanced the privatization of both the nonfinancial corporate and the banking sectors is and how much progress has been made in introducing bankruptcy laws, accounting standards and Western corporate governance. In particular, soft budgets may be due to open subsidies or implicit subsidies (tolerance of tax arrears, tax relief and tax concessions) from the government or easy access to new credits from state-owned banks. Soft budget constraints are still present at least in some sectors of less advanced transition countries, such as Bulgaria, Croatia and Romania, let alone the CIS countries (see Croitoru and Schaffer, 2002, for Romania). However, one may also argue that soft budget constraints mostly concern larger firms, which would otherwise be less subject to the credit channel.

112. If small firms' contribution to output is low, or if only a small fraction of (small) firms relies on bank lending, the macroeconomic impact of the bank lending channel will be negligible. ${ }^{42}$

41 Plus default risk, but this is also contained in the domestic interest rate.

42 The capitalization and liquidity position of the firms are also important for the functioning of the credit channel. Although large firms may also be weakly capitalized and less liquid, small firms usually are less capitalized and less liquid than large firms. 
113. If the distribution of small firms differs across sectors, the impact of monetary policy acting via the credit channel may be heterogeneous across sectors. In particular, the share of small firms in output is considerably larger in the nontradable than in the tradable sector (Tornell and Westermann, 2002). Hence, the credit channel may be more important for the nontradable sector. ${ }^{43}$

114. In general, the macro-evidence of the bank lending channel in industrialized economies seems to be fairly weak. However, loans to households may be more responsive to monetary policy shocks than corporate loans. Even so, the extent to which those changes matter for household consumption remains controversial. The use of micro bank and firm-level data suggests that bank lending activity may be affected by monetary policy. However, there is no consensus on which characteristics of banks (size, liquidity, capitalization) matter most. The second stage of the bank lending channel appears to be more debated, as some authors point out the existence of a broad lending channel instead of a bank lending channel. In addition, trade credit seems to be an important source of external financing for firms with no credit rating.

\subsection{Empirical Evidence for CEE}

\subsubsection{Evidence from VAR}

115. The first stage of the bank lending channel is either assessed on the basis of VAR models or using bank-level data. Let us first take a look at the few VAR results. For Poland, Wróbel (2001) shows that a shock in short-term interest rates causes real credit to drop in the short run and to stabilize at a lower level afterward. Creel and Levasseur (2005) find that after the initial decrease, credit recovers for Poland. For the Czech Republic and Hungary, the results indicate a short-term rise, rather than a fall in the credit series after a monetary policy shock. Finally, Héricourt (2005) studies the impact of a credit shock on output and prices. The general outcome is that a credit shock temporarily increases both output and prices (for Poland, Slovakia and Slovenia).

\subsubsection{Evidence from Bank-Level Data}

Turning to the micro data-based evidence, this strand of the literature uses a variant of the approach taken in Ehrmann et al. (2001), which, in turn, is an improvement of Kashyap and Stein (2000):

$$
\Delta L_{i t}=\sum_{j=1}^{4} \alpha \Delta L_{j_{i t-j}}+\sum_{j=1}^{4} \beta_{j} M_{i t-j}+\sum_{j=1}^{4} \beta_{j} Y_{t-j}+\sum_{j=1}^{4} \lambda_{j} \Delta P_{t-j}+C_{i t-1}\left(\phi+\sum_{j=1}^{4} \eta_{j} M_{i t-j}+\sum_{j=1}^{4} \kappa_{j} Y_{i t-j}+\sum_{j=1}^{4} \pi_{j} \Delta P_{t-j}\right)
$$

where $\Delta L_{i t}$ is the loan supply growth rate for bank i for period t, M measures monetary policy, $\mathrm{Y}$ is real output and $\mathrm{C}$ denotes bank characteristics. Note that equation (5) is usually estimated separately for different bank characteristics $(C)$. That is, a separate regression is run, for instance, for size, liquidity, capitalization and ownership structure. Horváth, Krekó and Naszódi (2005) extend this list with the average cost of funds. Note, however, that a number of authors also simultaneously include all bankspecific characteristics (e.g. Havrylchyk and Jurzyk, 2005; Köhler, Hommel and Grote, 2005; Schmitz, 2004) or only two at the same time (Horváth, Krekó and Naszódi, 2005).

116. Overall, the empirical results strongly support the view that banks react differently to monetary policy changes depending on the above-listed characteristics. However, the bank-level characteristics are not equally important. For instance, Juks (2004) finds that the supply of household and corporate loans turn

43 It is interesting to note that the vast majority of empirical studies concentrate on the open sector, i.e. manufacturing. Hence, they may miss the point. 
out to be most affected for banks with a low level of liquidity, while bank size and capitalization does not matter. Merging data on aggregate loans for the three Baltic countries, Köhler, Hommel and Grote (2005) and Matousek and Sarantis (2006) come to a similar conclusion, although Matousek and Sarantis (2006) also find size to be an important factor. Bank capitalization may not matter for two reasons. First, capitalization measured at the bank level may not be an appropriate measure. Instead, the capitalization of an entire bank holding should be considered. Second, as also noted by Ehrmann et al. (2001), bank capitalization is high enough not to be affected by changes in monetary conditions. A final finding is that none of the three characteristics (size, liquidity and capitalization) are correlated with corporate loan supply in a robust manner.

117. In a similar vein, Schmitz (2004) shows for a set of CEE countries that size and the liquidity position seem to matter and that foreign-owned banks have a more pronounced reaction to a change in domestic and foreign monetary conditions than their domestic counterparts do. However, pooling all countries may mask considerable cross-country heterogeneities, as country-specific studies suggest. An excellent example is Matousek and Sarantis (2006), who cover the CEE-5 plus the three Baltic countries to show substantial country differences. In addition to the heterogeneity prevailing across countries, sometimes the results are quite colorful even for the very same country. Poland is a case in point. Havrylchyk and Jurzyk (2005) find that the better liquidity position enables banks to insulate loans from monetary policy actions. Weak evidence is also found for the size of the banks. However, the estimated coefficient indicates that smaller banks are in a better position to shield themselves from monetary policy. Finally, bank capitalization turns out to play no role in the lending behavior of banks. By contrast, Wróbel and Pawlowska (2002) find that size and capitalization explain bank lending behavior in the face of a monetary policy move in a standard manner (larger and more capitalized banks react less), while more liquid banks are more responsive to an increase in the policy rate than less liquid banks. This counterintuitive finding can be explained, according to the authors, by the over-liquidity of the Polish banking sector. The most robust variable in the regressions run by Chmielewski (2005) and by Matousek and Sarantis (2006) is capitalization, which indicates that better capitalized banks are shielded from the effects of monetary policy. Foreign involvement generally turns out to result in more responsiveness to monetary policy. The results for liquidity are in conformity with the findings in Wróbel and Pawlowska (2002). Finally, it deserves to be mentioned that the effect of bad loans may have opposite signs across different specifications, and, importantly, foreign currency-denominated loans, especially to households, are very insensitive to monetary policy actions.

118. For the Czech Republic, Matousek and Sarintis (2006) find that size, capitalization and liquidity are important from 1994 to 2003, whereas Pruteanu (2004) comes to the conclusion that better capitalized and more liquid banks appear to be less responsive to monetary policy from 1996 to 1998 but not from 1999 to 2001. In contrast, the result that larger banks and banks with more bad loans in their portfolio care less about monetary policy can lead back to the existence of a soft budget constraint mainly because of the unaccomplished privatization of the banking sector. In addition, it seems that size is especially important for foreign banks for which the coefficient switches sign between the two sub-periods. From 1996 to 1998, larger foreign banks were more affected by monetary policy actions, while from 1999 to 2001, smaller foreign banks were more responsive. Liquidity matters for foreign banks in the first sub-period, while it becomes important for Czech banks and foreign branches in the second sub-period.

119. For Hungary, Horváth, Krekó and Naszódi (2005) show that using more disaggregated loan series makes it is easier to pin down the bank lending channel and that all bank characteristics have a role to play, although their results also reveal that some of the bank characteristics are not particularly robust. This contrasts with Matousek and Sarintis (2006), who can identify size as the only variable explaining diverging bank lending activity as a result of monetary policy changes. Furthermore, the results reported in Horváth, Krekó and Naszódi (2005) indicate that foreign currency-denominated corporate loans are very unresponsive to monetary policy actions. 
120. Finally, according to Golodniuk (2005), Ukrainian banks react differently to changes only as a function of capitalization but not as a function of size and liquidity.

Table 3 Results of the Empirical Literature on CEE

\begin{tabular}{|c|c|c|c|c|c|c|c|}
\hline Author & Countr & Type of assets & Size & Liquidi & italiza & dd Lo & vners \\
\hline Schmitz (2004) & CEE-5 + B & 3Total loans & Yes & Yes & & -- & Yes \\
\hline Pruteanu (2004) & Czech Rep & uTotal loans - bad loans & Yes & Yes & Yes & Yes & Yes \\
\hline Matousek and Sarantis (20 & Czech Rep & uTotal loans & Yes & Yes & Yes & -- & -- \\
\hline Köhler et al. (2005) & B3, pooled & Total loans & & Yes & & -- & \\
\hline Matousek and Sarantis (20 & B3, pooled & Total loans & Yes & Yes & & -- & -- \\
\hline Juks (2004) & Estonia & Bank deposits & & & Yes & -- & -- \\
\hline & & HH loans & & Yes & & -- & -- \\
\hline & & COR loans & & $?$ & ? & -- & -- \\
\hline Horváth et al. (2005) & Hungary & $\begin{array}{l}\text { Total, domestic COR, HH lc } \\
\text { FX COR loans }\end{array}$ & Yes & Yes & Yes & $\begin{array}{l}-- \\
--\end{array}$ & $\overline{\text { Yes }}$ \\
\hline Matousek and Sarantis (20 & Hungary & Total loans & Yes & & & -- & -- \\
\hline Havrylchyk and Jurzyk (20 & Poland & Total loans & $?$ & Yes & & -- & -- \\
\hline & & Deposits & & & & -- & -- \\
\hline Wróbel and Pawloska (20 & Poland & Total loans & Yes & & Yes & -- & -- \\
\hline Chmielewski (2005) & Poland & HH loans - DC & & & Yes & Yes & Yes \\
\hline & & HH loans - FX & & & & Yes & \\
\hline & & COR loans - DC & & & Yes & Yes & Yes \\
\hline & & COR loans - FX & & & Yes & Yes & Yes \\
\hline Matousek and Sarantis (20 & Poland & Total loans & & & Yes & -- & -- \\
\hline Matousek and Sarantis (20 & Slovakia & Total loans & $?$ & $?$ & $?$ & -- & -- \\
\hline Matousek and Sarantis (20 & Slovenia & Total loans & $?$ & $?$ & $?$ & -- & -- \\
\hline Golodniuk (2005) & Ukraine & Total loans & & & Yes & -- & -- \\
\hline & & Consumer loans & & & Yes & -- & - \\
\hline
\end{tabular}

Note: indicates weak evidence in favour of the given variable. HH and COR stand for households and the nonfinancial corporate sector. DC stands for loans denominated in domestic currency, FX for those in foreign currency. CEE-5 stands for the Czech Republic, Hungary, Poland, Slovakia and Slovenia; B3 stands for the three Baltic countries.

\subsection{Some Criticism}

121. A number of critical remarks about the literature aimed at studying the credit channel in CEE are in order. The literature is still very scarce and deals with selected aspects of the credit channel. No attempt has been made so far to systematically investigate how interest rates affect credit aggregates and how changes in credit aggregates influence output and prices. This is particularly true of micro-based panel studies, which have yet to analyze the second stage of the bank lending channel. As we know, even though bank lending behavior is influenced by monetary policy steps, for the bank lending channel to be operational, firms must be found to rely solely on bank loans.

122. Chmielewski (2005) provides a good example in looking at loan series split into domestic and foreign currency denominations and into corporate and household loans. Perhaps a little more disaggregation into different segments of the corporate and household market (short-term, long-term, consumer, housing and automobile credit) would help us understand better how, if at all, the credit channel works in CEE. A remaining future challenge is to obtain estimates from bank- and firm-level datasets of the adjustment in output and prices in the aftermath of a change in monetary policy.

123. But perhaps the most important shortcoming of the literature relating to the credit channel in general is that it assumes that credit markets are in equilibrium and that the credit series used for estimations reflect this equilibrium. However, disequilibrium in the credit market may have important implications for monetary policy. If there is excess demand for credit, banks tend to ration credit and may thus amplify (attenuate) the effect of a monetary policy tightening (loosening). In contrast, if the supply of 
credit exceeds the demand for credit, perhaps because banks hold too much liquidity, banks will not pass changes in the policy rate through to their retail rates in the event of a monetary policy tightening, ${ }^{44}$ because this would reduce the demand for credit, which is already insufficient to clear the market. Nonetheless, an interest rate cut would be very quickly incorporated into loan rates (Hurlin and Kierzenkowski, 2002, 2003). Hurlin and Kierzekowski (2003) identify excess credit supply until mid-1999 and a regime of excess demand for credit in Poland and argue that the existence of these two regimes may explain why Polish monetary policy became much more efficient after 1999.

\section{The Asset Price Channel}

\subsection{The Background}

124. The asset price channel is potentially important in transmitting the effects of monetary policy to prices and the real economy. From a monetarist viewpoint, in the event that an expansionary monetary policy results in increased money supply, the actual level of liquidity held by the public will exceed its desired level. This, in turn, leads market participants to seek to decrease liquidity at their disposal by buying equity, bonds and housing, which results in a rise in the respective prices. An increase in bond prices is automatically translated into a decrease in the interest rate, which is already under pressure through the interest rate channel. Falling interest rates will then increase the attractiveness of equities, fueling equity purchases and causing equity prices to rise further. However, asset price reactions to monetary policy action can be asymmetric in nature (Ehrmann and Fratzscher, 2004).

125. Higher equity prices eventually exert an influence on investment spending by altering the relationship between the cost of capital and the stock market valuation of that capital. This mechanism is described by Tobin's $Q$ theory, where $\mathrm{Q}$ is defined as the market value of firms over the replacement cost of capital. Similarly, an increase in equity prices also affects household spending via the wealth effect. The basic idea behind $\mathrm{Q}$ is that as Q rises above unity, firms find their market value to be high relative to the replacement cost of capital; therefore, new investments are cheaper relative to the market value of firms. As a consequence, issuing fewer new shares at high prices enables firms to buy more new equipment at lower prices, which results in higher investment spending.

126. The Q theory is also applicable to the housing market. For example, a higher-than-unity Q implies a market value above replacement cost, which promotes construction output. Conversely, if $\mathrm{Q}$ is below 1, firms would not seek to buy new equipment because it is more advantageous to acquire other firms with a market value below their replacement cost of capital. Likewise, it is more favourable to buy old houses instead of constructing new ones. As a result, investment, household spending and construction activity decrease.

127. The wealth effect channel of equity and property prices is closely related to Modigliani's lifecycle theory, in which household consumption spending is believed to be driven by disposable lifetime wealth. Because equity and property is part of this wealth, a rise (fall) in equity and housing prices triggered by monetary policy action results in increasing (diminishing) lifetime wealth and thus leads to an increase (decrease) in consumption spending.

128. An alternative view to the wealth effect is the so-called liquidity effect. In line with Mishkin (2001), spending on durable goods and housing is to a large extent influenced by consumers' perception of the likelihood of running into financial difficulties. The higher the ratio of liquid financial assets to debt is, the lower the probability of financial distress will be. Thus, an increase in equity prices decreases the

44 This connection shows how the state of the credit market influences the interest rate pass-through. 
danger of future problems related to debt and therefore encourages households to consume more goods and housing.

129. It is noteworthy mentioning that the asset price channel interferes with other channels of the monetary transmission mechanism, and hence may amplify the overall transmission, mainly through the broad lending channel. A rise (fall) in the price of an asset (such as stocks, bonds or housing) triggered by monetary policy action strengthens (weakens) the balance sheet of firms and households. This, in turn, increases (lowers) their capacity to borrow from external sources because of the lower (higher) external financing premium.

130. If the credit channel is operational, an increase (decrease) in interest rates can lead to a drop (rise) in the stock price of firms which are subject to financial constraint because such firms are unable to supply their preferred amount of goods and services, so their expected future profits fall. This effect, in turn, has a feedback effect on the credit channel, since a change in stock prices changes the external financing premium (plus the wealth effect) of the firm and of firms and households that hold shares of the firm.

\subsection{Stylised Facts in CEE}

131. Rezessy (2005) provides evidence for momentary policy shocks impacting government bond yields but not stock prices in Hungary. Kiss and Vadas (2005) analyze asset prices - in particular housing prices - in monetary transmission in transition economies and find that both the wealth and the credit channel are at work in the Hungarian housing market, even though the effect of monetary policy has only a limited impact on house prices, housing investment and consumption. One important reason for this finding is that the institutional setting and public subsidy schemes insulate the housing market from monetary policy actions.

132. Given the lack of empirical evidence regarding the asset price channel, we provide hereafter some stylized facts about its importance that we think is still limited because of the stage of development and the characteristics of the capital markets. Table 4 below indicates that stock market capitalization and market turnover is fairly low in CEE as compared to the euro area. Bond markets matter even less as they are used for financing the public debt rather than raise new capital for private firms. ${ }^{45}$ But not only are these markets not very large, they are also dominated by foreign investors rather than by domestic ones, thus limiting the impact of changes in asset prices on domestic investment and consumption decisions through the wealth and income effects.

Table 4. Factors influencing the asset price channel

\begin{tabular}{|c|c|c|c|c|c|c|c|c|c|c|c|c|c|c|}
\hline \multirow[b]{2}{*}{$\%$ GDP if not indicated otherwise } & \multicolumn{5}{|c|}{ CEE5 } & \multicolumn{3}{|c|}{ B3 } & \multicolumn{3}{|c|}{ SEE } & \multicolumn{3}{|c|}{ EURO AREA } \\
\hline & $\mathrm{CZ}$ & $\mathrm{HU}$ & PL & SK & SI & $\mathrm{EE}$ & LV & LT & BG & HR & $\mathrm{RO}$ & EUR & MAX & MIN \\
\hline \multicolumn{15}{|c|}{ Stock markets - 2003} \\
\hline Capitalisation & 18.3 & 17.4 & 15.3 & 7.1 & 20.7 & 2.1 & 8.1 & 12.9 & 6.3 & 16.7 & 8.8 & 54.4 & 96.3 & 17.2 \\
\hline & 9.6 & 10.0 & 4.1 & 2.0 & 2.6 & 0.4 & 1.3 & 1.1 & 1.0 & 0.8 & 0.8 & 48.8 & 111.8 & 4.3 \\
\hline \multicolumn{15}{|c|}{ Bond markets - 2003} \\
\hline Priv & 7.2 & 3.4 & n.a. & n.a. & n.a. & n.a. & n.a. & n.a. & n.a. & n.a. & n.a. & 32.0 & 56.6 & 0.4 \\
\hline Put & 51.5 & 40.9 & 29.1 & n.a. & n.a. & n.a. & n.a. & n.a. & a. & n.a. & n.a. & 53.2 & 97.1 & 20.1 \\
\hline Total d & 0.3 & 0.0 & 6.0 & n.a. & 0.9 & 0.6 & n.a. & n.a. & n.a. & n.a. & n.a. & 12.9 & 50.4 & 0.6 \\
\hline \multicolumn{15}{|c|}{ Domestic investment funds } \\
\hline & 4 & 5.4 & 4.7 & 5. & 8. & 3.5 & 0.5 & n.a. & n.a. & n.a. & n.a. & 51.3 & & 9.5 \\
\hline Pension funds & 3.7 & 6.5 & 7.9 & NA & 2.0 & 1.9 & 0.4 & 0.1 & n.a. & n.a. & n.a. & 12.4 & 106.9 & 0.0 \\
\hline
\end{tabular}

Source: World Development Indicators (2004), European Central Bank (2005).

45 Nevertheless, euro adoption may facilitate issuing corporate bonds at the euro area corporate debt securities market (see Deutsche Bundesbank (2004) for the German case). 
133. VAR studies provide a (black-box) framework in which the impact of monetary policy shocks on prices, output and macroeconomic variables can be quantified. ${ }^{46}$ This section summarizes the main issues of this literature, namely the prize and exchange rate puzzles, and then presents the empirical findings for the CEEs.

\subsection{The Price Puzzle I}

134. A huge amount of effort has been devoted to uncovering the impact of an unexpected monetary policy shock on output and inflation. This literature has produced the so-called "price puzzle," according to which a monetary policy contraction causes a rise in the inflation rate rather than a drop. While some authors qualified only the response of prices nonsensical and went on interpreting the reaction of the other variables to the shock, the vast majority of researchers have argued that the price puzzle invalidates all the other responses as well. In this spirit, several suggestions have been proposed to deal with this problem. ${ }^{47}$

135. A first group of papers, including that of Sims (1992), claimed that the forward-looking component of the monetary policy shock might have been misidentified, and the inclusion of commodity prices in the system makes the puzzle disappear. The underlying idea of this line of thinking is that policymakers in central banks also look at variables that are disregarded by academic studies and that help forecast inflation. Yet VAR models extended in this manner usually include only up to eight or ten variables, which represent only a small proportion of the information set available to policymakers. The combination of factor analysis with VAR models, which gives rise to factor-augmented VARs (FAVARs), provides a remedy to this problem. In such a setting, a small number of factors (principal components) summarizes the information extracted from a large number (perhaps over 100) of time series (Bernanke, Boivin and Eliasz, 2005).

136. However, Giordani (2004) and Hanson (2004) argue that variables good at predicting inflation (such as accurate inflation forecasts) are not helpful in solving the price puzzle. Giordani (2004) emphasizes the need to use the output gap as a remedy for the puzzle. Indeed, commodity prices may help to mitigate the puzzle only because they are correlated with the U.S. business cycle. Hanson (2004) shows that the price puzzle is due to the fact that the estimated VAR models cover periods during which there is a change in the monetary policy rule. Once the period is carefully hand-picked to remove overlaps between different monetary policy rules, the price puzzle disappears.

137. Another strand of the literature, initiated by Barth and Ramey (2000), takes the position that the price puzzle is not generated by methodological problems. Instead, prices tend to rise in the wake of a monetary policy tightening because an increase in interest rates gives rise to higher production costs reflected in higher inflation rates. They find that the so-called cost channel was more important during the 1960 s and 1970s and then declined during the 1980s and the 1990s in the U.S. economy. ${ }^{48}$ For small open

46 Note that aggregate structural models of the economy can be also viewed as black boxes because they provide little guidance for the channels that cause changes in output and prices in the aftermath of a monetary policy or exchange rate shock.

A more fundamental criticism of the VAR literature formulated by Bernanke, Gertler and Watson (1997) and McCallum (1999) is that VAR models capture only unanticipated changes in monetary policy rather that the systematic relationships that connect monetary policy instruments and the economy. Accounting for long-run relations is all the more import, as the unexpected component of monetary policy represents only a small fraction of changes in monetary policy (McCallum, 1999).

As they put it, unexpected monetary policy shocks can be best viewed as a combination of cost (supply) shocks and demand shocks. 
economies, the price puzzle is likely to arise if the nominal exchange rate is not included in the VAR (Kim and Roubini, 2000). More generally, Chowdhury et al. (2006) finds that the cost channel differ substantially across G-7 countries and that it is more important in the US than in European countries.

138. Finally, Kapinos (2004) observes that papers using monthly data tend to find evidence for the cost channel, whilst studies that analyse quarterly data do not support the cost channel. He uses the same dataset at different frequencies and shows that the cost channel tends to be short lived. This is why it shows up in monthly data but not in quarterly data.

\subsection{Price Puzzle II}

139. In the meantime, a price puzzle seems to be taking shape for emerging market economies. In these countries, a monetary restriction causes a rise in inflation if public debt is high. According to this view, a monetary policy tightening reflected in higher real interest rates increases the probability that the government will default as a consequence of higher interest payments. Hence, the risk premium rises, pushing foreign capital to leave the country, which, in turn, causes the exchange rate to depreciate. If the exchange rate pass-through to domestic prices is high enough, such a depreciation leads to rising inflation (Blanchard, 2004, and Favero and Giavazzi, 2004). ${ }^{49,50}$

\subsection{The Exchange Rate Puzzle}

140. Mojon and Peersman (2001) detect an exchange rate depreciation in the aftermath of a monetary policy innovation for Italy and Spain, which had trouble defending their exchange rate in 1993. This socalled exchange rate puzzle can be traced back to the fact that monetary policy reacted with an increase in short-term interest rates, mostly in vain. This also helps explain the price puzzle because nominal exchange rate depreciation feeds into domestic inflation (exchange rate pass-through). Nonetheless, if monetary policy shocks are in fact a response to changes in the exchange rate, then the issue at hand is the misidentification of monetary policy shocks, leading to a basic dismissal of the results.

\subsection{Empirical Findings for CEE}

141. Heterogeneity in results is an accompanying phenomenon of the ever growing number of VAR studies with a focus on CEE. According to table 5, which reports the main conclusions of the individual papers, all kinds of results can be found for a given country. In this sense, the price puzzle, a permanent decline or a temporary fall in the inflation rate after a monetary policy contraction can be obtained for the same country. Also, output may increase, decline permanently or exhibit a humped shape following a monetary policy shock. However, it turns out that studies that cover the entire transition period ${ }^{51}$ starting in

49 Recall that Burstein et al. $(2002,2004)$ show that the inflationary effect of a large devaluation will be limited because of the distribution-related component of goods sold to the consumers and because of the switch from imported goods to domestic substitutes.

50 The price puzzle was developed in the context of Brazil. It also applies to the case of other large emerging markets such as Turkey (Aktas et al., 2005).

51 Quite surprising is the fact that European Forecasting Network (2004) estimates a VAR for Hungary for a period starting in 1985. Obviously, it is difficult to obtain meaningful results when a period covers the end of central planning, the early and the later stages of the transition process. 
the early 1990s and that rely on recursive VAR models (European Forecasting Network, 2004; Creel and Levasseur, 2005; Héricourt, 2005) tend to obtain a price puzzle. In contrast, papers allowing for changes in the parameter estimates either by splitting the whole sample into subsamples (Arnostova and Hurník, 2004; Vonnák, 2005), by relying on genuine time-varying coefficient estimates (Darvas, 2005) or by employing a more sophisticated and hence more precise identification scheme of monetary policy innovation (Vonnák, 2005; Jarociński, 2005) find less evidence for that. The price puzzle in the Czech Republic may be due to the emergence of the exchange rate puzzle during the 1997 period (Arnostova and Hurník, 2004). Jarociński (2005) compares the mean of the impulse response functions of four CEE economies (the Czech Republic, Hungary, Poland, Slovenia) to that of five euro area countries (Finland, France, Germany, Italy and Spain) and finds that the reaction of prices and output to monetary policy shocks is stronger in CEE than in the euro area.

142. In sum, as put forth by Elbourne and de Haan (2004) for industrialized countries, the main sources of cross-study heterogeneity in results are (1) the different time period, (2) the use of different schemes to identify monetary policy shocks, and (3) the use of a different set of variables. ${ }^{52}$

Table 5 Summary of VAR Results

\begin{tabular}{|c|c|}
\hline Author & Results \\
\hline Arnostova and Hurník (2004) & $\begin{array}{l}\text { CZ, full period: foreign exchange and price puzzle, output: U-shaped } \\
1998 \text {, price and output: U-shaped, no foreign exchange puzzle }\end{array}$ \\
\hline Bitans et al. (2003) & LV, prices: slow decrease and then slow recovery \\
\hline Creel and Levasseur (2005) & $\begin{array}{l}\text { Inflation: price puzzle for all countries } \\
\text { Output increases for } 1999 \text { to } 2004 \text {, no reaction for HU }\end{array}$ \\
\hline Darvas (2005) & $\begin{array}{l}\text { Price puzzle in CZ }(1998,2004), \mathrm{HU}(1994,1998) \text {, drop in prices in PL } \\
\text { Output: drops most in PL, least in HU, but recovers more quickly in PL than in HU } \\
\text { Response profiles change over time }\end{array}$ \\
\hline EFN (2004) & $\begin{array}{l}\text { Mostly not significant (EE, SI, LT) } \\
\text { Inflation: CZ price puzzle, HU, LV U-shaped, SK permanent decrease (Q), U-shaped (M), PL } \\
\text { significant change }(\mathrm{Q}, \mathrm{M}) \\
\text { Output: } \mathrm{CZ}, \mathrm{HU} \text { U-shaped; PL strong drop then recovery }(\mathrm{M}), \mathrm{SK} \text { permanent increase } \\
\end{array}$ \\
\hline Elbourne and de Haan (2006) & $\begin{array}{l}\text { CEE-10; inflation: largest and quickest drop in SK and RO; PL, CZ protracted, others small; } \mathrm{H} \\
\text { price puzzle } \\
\text { Output: large and quick drop; CZ mostly quick; SK and EE slow }\end{array}$ \\
\hline Ganev et al. (2002) & $\begin{array}{l}\text { Inflation: SI, CZ permanent rise, LV, SK temporary fall, } \mathrm{HU} \text { permanent fall } \\
\text { Output: decrease is fastest in } \mathrm{HU} \text {, more permanent in } \mathrm{CZ} \text {, decreases and adjustment in } \mathrm{SK} \text { and } \\
\text { increases in the remaining countries; } \mathrm{BG}, \mathrm{RO} \text { : large fluctuations }\end{array}$ \\
\hline Héricourt (2005) & $\begin{array}{l}\text { Inflation: CZ, price and foreign exchange puzzle; HU, SI price puzzle } \\
\text { Output: CZ, GDP and IIP different } \\
\text { EE, PL, SK: no significant change }\end{array}$ \\
\hline Jarociński (2005) & CEE-4: decline in output and prices \\
\hline Kuijs (2001 & M2 shock: SK, increase in inflation (unit labour cost increase), little impact on output. \\
\hline Maliszewski (1999) & $\begin{array}{l}\text { Inflation: PL declines and recovers partially } \\
\text { Output: PL declines and recovers partially (more strongly than inflation) }\end{array}$ \\
\hline Maliszewski (2002) & $\begin{array}{l}\text { Inflation: CZ, PL slow decline and stabilization at lower level } \\
\text { Output: CZ, PL hump-shaped, but not full recovery }\end{array}$ \\
\hline Vonnák (2005) & $\begin{array}{l}\text { HU: } 1992 \text { to } 2003 \text { price puzzle } \\
\text { HU: } 1995 \text { to } 2003 \text { quick decline in output, slow decline in prices, currency appreciation }\end{array}$ \\
\hline Wróbel (2001) & $\begin{array}{l}\text { Prices: PL increase followed by decrease and slight recovery, but still negative } \\
\text { Output: PL increase followed by decrease and full recovery } \\
\text { Credit: PL large decrease followed by slow recovery }\end{array}$ \\
\hline
\end{tabular}

52 Héricourt (2005) also argues that it does matter whether one employs industrial production or GDP figures for output. 


\section{Concluding Remarks}

143. The determinants of the different channels of the transmission mechanism set out in this paper may give us some clues about the past and possibly about the future development of the different channels. ${ }^{53}$ Starting with the very first step of the transmission mechanism, the interest rate pass-through improved substantially from the beginning of transition until recently, both in terms of the speed of adjustment toward long-term pass through and of the size of the long-run pass-through, mostly because of the development of the financial and banking sectors in these countries.

144. Speculating about the future from a macro-perspective, money market volatility is bound to fall to euro area levels after euro adoption, and financial depth is likely to rise in the years to come. At the same time, inflation rates will close the gap to the inflation rate of the euro area, and long-run GDP growth may slow down as real convergence progresses. The first two factors will work toward an increase in the pass-through while the next two variables could dampen it. Looking at the structure of the banking sector, e.g. Poland, Slovenia and Latvia have fewer foreign investors, partly because of slower banking sector reform. Poland and Slovenia are the countries with the highest burden of nonperforming loans, and Slovenia has the lowest capital adequacy ratio, which is comparable to that of the euro area, however. All this is admittedly detrimental to the interest rate pass-through. So, by making efforts on the front of banking reforms, these countries would be able to enhance the interest rate pass-through. However, market concentration has recently been on the rise in most of these countries. Very high concentration rates can be observed in Estonia and Lithuania, while concentration is lowest in Hungary and Poland. Generally, market concentration is higher than in the euro area and is still on the rise, indicating to our minds that the interest rate pass-through may slow down and become less complete in the future in these countries.

145. The lack of empirical evidence on the monetary channel does not mean that this channel is negligible (or will remain so-). In fact, progress in financial deepening, in particular the increase of domestic credit to households will probably strengthen the monetary channel. A higher interest rate level will increase the debt service squeezing household demand for goods and services. A higher interest rate will also favour savings over consumption (substitution effect).

146. Let us now turn to the relation between monetary policy, the exchange rate and prices. There is little evidence for the link between the policy rate and the exchange rate. While VAR studies come to mixed conclusions, alternative econometric techniques and the event study approach help us identify that policy rates indeed have an impact on the exchange rate. This is crucial for the second stage of the exchange rate pass-through. Regarding the pass-through from the exchange rate to prices, the exchange rate pass-through has decreased over time and is expected to be stabilizing at a lower level despite that trade and import exposure rose sharply in all countries except for Slovenia. The main reason for this decrease is the steady fall in inflation rates to very low levels in all countries, perhaps with the exception of Romania and Russia, and the abandonment of accommodative monetary policies. The composition effect, measured as an increase in the share of manufactured goods in total imports, is fairly substantial in all countries, with the exception of Slovenia. However, its role is not clear-cut, given that the pass-through for this group of goods is found to be higher on occasion than for more homogeneous goods. Even so, and because of an expected decline in relatively high inflation volatility and exchange rate volatility, the exchange rate channel will lose its prominent role in the monetary transmission mechanism, if it has not done so already. However, changes in the exchange rate may have a strong impact on the balance sheet of firms and households, if there is a currency mismatch between revenues and expenditures. Currency mismatch may be an issue because of the recent surge in foreign currency-denominated household loans and, to a lesser extent, in loans to the corporate sector. After euro adoption, the effect of the pass-through will come directly from trade with countries outside the euro area, and indirectly via the direct impact of

53 Without considering the influence of financial crisis started in autumn 2008 and its aftermath. 
the major currencies' fluctuations against the euro (EUR/JPY, EUR/GBP and EUR/USD) on the main euro area trading partners, such as Germany, France and Italy.

147. The asset price channel is still of limited importance and is probably going to remain a lowprofile transmission channel. Stock and bond markets matter little to investment and consumption decisions through the wealth and income effects, given that these markets are dominated massively by foreign investors rather than by domestic ones. As a consequence, price movements on these markets have a limited impact on the domestic economy via these two effects. The shift from pay-as-you-go pension systems towards (partially) privately funded pension systems could increase the role of capital markets to the extent that pension funds are allowed to invest in stock and private bonds. Even though the effect of monetary policy via the property market does not appear to be very important for the time being, this channel may grow more powerful in the future with the dynamic development of borrowing related to housing.

148. The limited role of the capital market manifests itself not only for the asset price channel, but has also important implications for the credit channel. Obviously, new funds raised on both stock and bond markets are virtually close to zero in CEE, as only a very limited number of companies get listed on the stock market and as bond markets are used for financing public debt. This is unlikely to change in the near future. As a consequence, one may think that the financing of the nonfinancial corporate sector transits through the banking sector.

149. Nonetheless, there are several factors that may weaken the credit channel. First, the high concentration of the banking sectors, the heavy involvement of foreigners, the high degree of liquidity and more than sufficient levels of bank capitalization render banks less responsive to domestic monetary policy impulses. Second, notwithstanding the absence of well functioning capital markets, firms may escape from domestic credit markets either by borrowing in foreign currency or by relying on trade credit and other kinds of interfirm loans relating to transnational networks created by FDI.

150. The moderately good news for the effectiveness of monetary policy is, however, that firms capable of escaping domestic monetary policy conditions are strongly influenced by monetary policy in the euro area either because foreign currency loans are denominated in euro, or because their parent institutions are themselves subjected to the credit channel in the euro area.

151. When looking at the recipient sectors and the distribution of small and large firms across sectors, it appears that the manufacturing sector is less subject to the credit channel than the rest of the economy, in particular the service sector. First, FDI inflows to manufacturing are disproportionately high. Second, small firms are mostly concentrated in nontradables. Argued the other way around, the credit channel is likely to be operational for the market-based nontradable sector and may have a strong impact on this part of the economy. Even though services account for about $70 \%$ of GDP in most countries, the country-specific impact is heterogeneous depending on how large the contribution of small firms to GDP is and how large public involvement in nontradable sectors is.

152. In addition, households mainly rely on bank borrowing. ${ }^{54}$ We will witness the emergence and a subsequent strengthening of the credit channel for households with a higher level of household loans. However, monetary policy will affect this segment of the economy only partially and relatively slowly, given that the interest rate pass-through is lowest and most sluggish for consumer loans. As we argued earlier, the interest rate pass-through may slow down in the course of the coming years. This may indeed further cushion the impact of monetary policy through the credit channel.

54 Note, however, that nonbanking financial institutions gained market shares in the mortgage market until 2007. 
153. Finally, while the credit channel is likely to be at work or to gain importance in the nontradable sector and in the household sector, the interest rate channel may have a larger impact on the manufacturing sector. The final impact of monetary policy on output and prices of the manufacturing sector depends crucially on how parts of manufacturing react to changes in the interest rate. Although the share of manufacturing is fairly stable at around $20 \%$ for all countries under study, its composition differs substantially from country to country. For instance, food production plays an important role in Poland, Bulgaria, Croatia and Romania, while the Czech Republic, Hungary and Slovakia excel in producing electrical, optical and transport equipment. To the extent that these sectors differ in terms of mark-up (high or low mark-up sectors), they may have different reactions in different channels, as we set out above. Hence, a heterogeneous response of these sectors to monetary policy innovations may generate substantial cross-country heterogeneity to monetary policy impulses. 


\section{REFERENCES}

Adams, R. M. and D. F. Amel. 2005. The Effects of the Local Banking Market Structure on the Bank Lending Channel of Monetary Policy. The Federal Reserve Board. Finance and Economics Discussion Series No. 16.

Akerlof, G. 1970. The Market of 'Lemons': Qualitative Uncertainty and the Market Mechanism. Quarterly Journal of Economics. 84(3). 488-500.

Aktaş, Z., N. Kaya and Ü. Özlale. 2005. The Price Puzzle in Emerging Markets: Evidence from the Turkish Economy Using Model Based Risk Premium Derived from Domestic Fundamentals. Central Bank of the Republic of Turkey Working Paper No. 2.

Alexandre, F. 2002. Monetary Policy. Investment and Non-Fundamental Shocks. Birkbeck College. Mimeo.

Angeloni, I, A. K. Kashyap, B. Mojon and D. Terlizzese. 2003. The Output Composition Puzzle: A Difference in the Monetary Transmission Mechanism in the Euro Area and U.S.A. Journal of Money, Credit and Banking 35(6). 1265-1306.

Arnoštova, K. and J. Hurník. 2004. The Monetary Transmission Mechanism in the Czech Republic: Evidence from the VAR Analysis. Paper presented at the $3^{\text {rd }}$ Macroeconomic Policy Research Workshop on October 29-30, 2004. Magyar Nemzeti Bank.

Árvai, Z. 1998. The Interest Rate Transmission Mechanism between Market and Commercial Bank Rates. National Bank of Hungary Working Paper No. 10.

Ashcraft, A. B. 2001. New Evidence on the Lending Channel. Federal Reserve Bank of New York Staff Reports No. 136.

Bailliu, J. and E. Fujii. 2004. Exchange Rate Pass-Through and the Inflation Environment in Industrialized Countries: An Empirical Investigation. Bank of Canada Working Paper No. 21.

Bank for International Settlements. 2005. Foreign Exchange Market Intervention in Emerging Markets: Motives. Techniques and Implications. BIS Papers No. 24.

Barth, M. J. and V. A. Ramey. 2000. The Cost Channel of Monetary Policy. NBER Working Paper No. 7675 .

Baxter, M. 1994. Real Exchange Rates and Real Interest Rate Differentials: Have we Missed the Business Cycle Relationship? Journal of Monetary Economics 33. 5-37.

Bernanke, B. S. and A. Blinder. 1988. Credit, Money and Aggregated Demand. American Economic Review Proceeding Papers. 78(2). 435-439. 


\section{ECO/WKP(2008)62}

Bernanke, B. S. and M. L. Gertler. 2000. Monetary Policy and Asset Price Volatility. NBER Working Paper No. 7559.

Bernanke, B. S., J. Boivin and P. Eliasz. 2005. Measuring the Effects of Monetary Policy: A FactorAugmented Vector Autoregressive (FAVAR) Approach. Quarterly Journal of Economics 120(1). $387-422$

Bernanke, B. S., M. L. Gertler and M. Watson. 1997. Systematic Monetary Policy and the Effects of Oil Price Shocks. C.V. Starr Center for Applied Economics. New York University Working Paper No. 25.

Bernanke, B. S. and M. L. Gertler 1995. Inside the black box: The credit channel of monetary policy. Journal of Economic Perspectives 9(4). 27-48.

Bernstein, S. and R. Fuentes. 2003. Is there lending rate stickiness in the Chilean banking industry? Central Bank of Chile Working Paper No. 218.

Bitāns, M. 2004. Pass-Through of Exchange Rates to Domestic Prices in East European Countries and the Role of Economic Environment. Bank of Latvia Working Paper No. 4.

Bitāns, M., D. Stikuts and I. Tillers. 2003. Transmission of Monetary Shocks in Latvia. Bank of Latvia Working Paper No. 1.

Blanchard, O. 2004. Fiscal Dominance and Inflation Targeting: Lessons from Brazil. NBER Working Paper No. 10389.

Blanchard, O. J., C. Rhee and L. Summers. 1993. The Stock Market. Profit and Investment. Quarterly Journal of Economics. 108. 115-136.

Blinder, A., M. Ehrmann, M. Fratzscher, J. de Haan and D-J. Jansen. 2008. Central Bank Communication and Monetary Policy: A Survey of the Evidence. Journal of Economic Literature (forthcoming)

Burstein, A., M. Eichenbaum and S. Rebelo. 2002. Why Are Rates of Inflation So Low After Large Devaluation? NBER Working Paper No. 8748.

Burstein., A., M. Eichenbaum and S. Rebelo. 2004. Large Devaluations and the Real Exchange Rate. CEPR Discussion Paper No. 4810.

Burstein, A., J. C. Neves and S. Rebelo. 2004. Investment Prices and Exchange Rates: Some Basic Facts. NBER Working Paper No. 10238.

Ca'Zorzi, M., E. Hahn and M. Sanchez. 2007. Exchange Rate Pass-Through in Emerging Markets. ECB. Working Paper No. 739.

Campa, J. M. and L. S. Goldberg. 1995. Investment, Pass-Through and Exchange Rates: A Cross-Country Comparison. NBER Working Paper No. 5139.

Campa, J. M. and L. S. Goldberg. 2002. Exchange Rate Pass-Through into Import Prices: A Macro or Micro Phenomenon? NBER Working Paper No. 8934.

Canales-Kriljenko, J. I. 2003. Foreign Exchange Intervention in Developing and Transition Economies: Results of a Survey. IMF Working Paper No. 95. 
Carranza, L., J. E. Galdón-Sánchez and J. Gómez-Biscarri. 2004. Exchange Rate and Inflation Dynamics in Dollarized Economies. University of Navarra. Mimeo.

Cecchetti, S. G., H. Genberg, J. Lipsky and S. Waghwani. 2000. Asset Prices and Central Bank Policy. Geneva Reports on the World Economy No. 2. International Centre for Monetary and Banking Studies and CEPR.

Chatelain, J. B., A Generale, I. Hernando, U. von Kalckreuth and P. Vermeulen. 2001. Firm Investment and Monetary Transmission in the Euro Area. ECB Working Paper No. 112.

Chinn, M. D and G. Meredith. 2005. Testing Uncovered Interest Parity at Short and Long Horizons During the Post-Bretton Woods Area. NBER Working Paper No. 11077.

Chmielewski, T. 2003. Interest Rate Pass-Through in the Polish Banking Sector and Bank-Specific Financial Disturbances. paper presented at the ECB Workshop on Asset Prices and Monetary Policy. December 11-12, 2003.

Chmielewski, T. 2005. Bank Risks. Risk Preferences and Lending. National Bank of Poland. Mimeo.

Choudhri, E. U. and D. S. Hakura. 2001. Exchange Rate Pass-Through to Domestic Prices: Does the Inflationary Environment Matter? IMF Working Paper No. 194.

Choudri, E. U., H. Faruqee and D. S. Hakura. 2005. Explaining the Exchange Rate Pass-Through in Different Prices. Journal of International Economics 65. 349-374.

Chowdhury, I., M. Hoffmann and A. Schabert. 2006. Inflation dynamics and the cost channel of monetary transmission. European Economic Review 50(4). 995-1016.

Christiano, L. J., M. Eichenbaum and C. Evans. 1996. Identification and the effects of monetary policy shocks. Financial Factors in Economic Stabilization and Growth. M. Blejer, Z. Eckstein, Z. Hercowitz and L. Leiderman (eds,). Cambridge: Cambridge University Press. 36-74.

Coricelli, F., B. Jazbec and I. Masten. 2003. Exchange Rate Pass-Through in Acceding Countries: The Role of Exchange Rate Regimes. CEPR Discussion Paper No. 3894 and Journal of Banking and Finance. 30(5). 1375-1391.

Creel, J. and S. Levasseur. 2005. Monetary Policy Transmission in the CEECs: How Important are the Differences with the Euro Area. OFCE Working Paper No. 2.

Crespo-Cuaresma, J., B. Égert and T. Reininger. 2004. Interest Rate Pass-Through in New EU Member States: The Case of the Czech Republic, Hungary and Poland. William Davidson Institute Working Paper No. 671.

Crespo-Cuaresma, J., J. Fidrmuc, M-A. Silgoner. 2005. On the road: The path of Bulgaria, Croatia and Romania to the EU and the euro. Europe-Asia Studies 57. 843-858.

Croitoru, L. and M. E. Schaffer. 2002. Measurement and Assessment of Soft Budget Constraints in Romania. National Bank of Romania. Occasional Paper No. 2.

Dabušinskas, A. 2003. Exchange Rate Pass-Through to Estonian Prices. Bank of Estonia Working Paper No. 10. 
Darvas, Z. 2001. Exchange Rate Pass-Through and Real Exchange Rate in EU Candidate Countries. Deutsche Bundesbank Discussion Paper No. 10.

Darvas, Z. 2005. Monetary Transmission in the New Members of the EU: Evidence from Time-Varying Coefficient Structural VARs. Corvinus University Budapest. Mimeo.

De Bondt, G. 2002. Retail Bank Interest Rate Pass-Through: New Evidence at the Euro Area Level. ECB Working Paper No. 136.

Dedola, L. and F. Lippi. 2000. The Monetary Transmission Mechanism: Evidence from the Industries of Five OECD Countries. CEPR Discussion Paper No. 2508.

DeGennaro, R. P. 2005. Market Imperfections. Federal Reserve Bank of Atlanta Working Paper No. 12.

Deutsche Bundesbank. 2004. Neuere Entwicklungen am Markt für Unternehmensanleihen. Monatsbericht April.

Devereux, B. and J. Yetman. 2003. Price-Setting and Exchange Rate Pass-Through: Theory and Evidence. Proceedings of the conference Price Adjustments and Monetary Policy held at the Bank of Canada in November 2002. 347-371.

Disyatat, P. and G. Galati. 2005. The effectiveness of foreign exchange intervention in emerging market counties: Evidence from the Czech koruna. BIS Working Paper No. 172.

Dobrynskaya, V. and D. Levando. 2005. Exchange Rate Pass-Through Effect and Monetary Policy in Russia. Paper presented at the BOFIT/CEFIR Workshop on Russian Macroeconomic and Financial Issues. Moscow, April 8-9, 2005.

Edwards, S. 2006. The relationship between exchange rates and inflation targeting revisited. NBER Working Paper No. 12163.

Égert, B. 2007. Central bank interventions, communication and interest rate policy in emerging European economies. Journal of Comparative Economics. 35(2). 387-413.

Égert, B. and L. Komárek. 2006. Foreign exchange interventions and interest rate policy in the Czech Republic: Hand in glove? Economic Systems 30(2). 121-140.

Égert, B. and A. Morales-Zumaquero. 2008. Foreign exchange regimes, foreign exchange volatility and trade performance in the CEECs. Review of Development Economics. 12(3). 577-593.

Égert, B., J. Crespo-Cuaresma and T. Reininger. 2007. Interest Rate Pass-Through in Central and Eastern Europe: Reborn from Ashes to Pass Away? Journal of Policy Modeling. 29. 209-225.

Égert, B., L. Halpern and R. MacDonald. 2006. Equilibrium Exchange Rates in Transition Economies: Taking Stock of the Issues. Journal of Economic Surveys. 20(2). 257-324.

Égert, B. and R. MacDonald. 2006. Monetary Transmission Mechanism in Transition Economies: Surveying the Surveyable, Hungarian central bank Working Paper No. 2006/5.

Ehrmann, M. and A. Worms. 2004. Bank Networks and Monetary Policy Transmission. Journal of the European Economic Association. 2 (6). 1148-1171 (also as ECB Working Paper No. 73).. 
Ehrmann, M. and M. Fratzscher. 2004. Taking Stock: Monetary Policy Transmission to Equity Markets. Journal of Money, Credit and Banking 36(4). 719-737.

Ehrmann, M., L. Gambacorta, J. M. Pagés, P. Sevestre and A. Worms. 2001. Financial Systems and the Role of Banks in Monetary Policy Transmission in the Euro Area. ECB Working Paper No. 105.

Elbourne, A. and J. de Haan. 2004. Asymmetric Monetary Transmission in EMU: The Robustness of VAR Conclusions and Cecchetti's Legal Family Theory. CESifo Working Paper Series No. 1327.

Elbourne, A. and J. de Haan. 2006. Financial Structure and Monetary Policy Transmission in Transition Countries. Journal of Comparative Economics 34(1). 1-23.

Engel, C. 2002. The Responsiveness of Consumer Prices to Exchange Rates and the Implications for Exchange Rate Policy: A Survey of a Few Recent New Open-Economy Macro Models. NBER Working Paper No. 8725.

European Forecasting Network. 2004. Monetary Transmission in Acceding Countries. Annex. 97-142.

Fama, E. F. 1985. What's Different about Banks? Journal of Monetary Economics. 15(1). 29-39.

Favero, C. and F. Giavazzi. 2004. Inflation Targeting and Debt: Lessons from Brazil. NBER Working Paper No. 10390.

Filardo, A. 2004. Monetary Policy and Asset Price Bubbles: Calibrating the Monetary Policy Trade-Off. BIS Working Paper No. 155.

Frankel, J. A., D. C. Parsley and S. J. Wei. 2005. Slow Pass-Through Around the World: A New Import for Developing Countries. NBER Working Paper No. 11199.

Gagnon, J. E. and J. Ihrig. 2001. Monetary Policy and Exchange Rate Pass-Through. Board of Governors of the Federal Reserve System. International Finance Discussion Papers No. 704.

Gambacorta, L. 2004. How Do Banks Set Interest Rates? NBER Working Paper No. 10295.

Gambacorta, L. 2005. Inside the Bank Lending Channel. European Economic Review. 49(7). 1737-1759.

Ganev, G., K. Molnár, K. Rybiński and P. Woźniak. 2002. Transmisson Mechanism of Monetary Policy in Central and Eastern Europe. CASE Reports No. 52.

Gereben, Á., G. Gyomai, M. N. Kiss. 2006. Customer order flow, information and liquidity on the Hungarian foreign exchange market. Central bank of Hungary Working Paper No. 8

Geršl, A. and T. Holub. 2006. Foreign exchange interventions under inflation targeting: The Czech experience. Contemporary Economic Policy 24(4), 475-491.

Giordani, P. 2004. An Alternative Explanation of the Price Puzzle. Journal of Monetary Policy 51(6). $1271-1296$.

Golodniuk, I. 2005. Evidence on the Bank Lending Channel in Ukraine. Paper presented at the Second Meeting of the UACES Study Group on Monetary Policy in Selected CIS Countries. Helsinki, February 10-11, 2005. 


\section{ECO/WKP(2008)62}

Gueorguiev, N. 2003. Exchange Rate Pass-Through in Romania. IMF Working Paper No. 130.

Hannan, T. H and A. N. Berger. 1991. Rigidity of Prices: Evidence from the Banking Industry. American Economic Review. 81(4). 938-945.

Hanson, M. S. 2004. The "Price Puzzle" Reconsidered. Journal of Monetary Economics. 51(7). 13851413.

Havrylchyk, O. and E. Jurzyk. 2005. Does the Bank Lending Channel Work in a Transition Economy? A Case of Poland. European University Viadrina. Mimeo.

Héricourt, J. 2005. Monetary Policy Transmission in the CEECs: Revisited Results Using Alternative Econometrics. University of Paris 1 . Mimeo.

Hoffmann, M. and R. MacDonald. 2006. A Re-examination of the link between Real Exchange Rate and Real Interest Rate Differentials. University of Glasgow Department of Economics Working Paper No. 36 .

Holub, T. 2004. Foreign Exchange Interventions Under Inflation Targeting: The Czech Experience. Czech National Bank Internal Research and Policy Note No. 1.

Horváth, C., J. Krekó and A. Naszódi. 2004. Interest Rate Pass-Through: The Case of Hungary. National Bank of Hungary Working Paper No. 8.

Horváth, C., J. Krekó and A. Naszódi. 2005. Is There a Bank Lending Channel in Hungary? National Bank of Hungary. Mimeo.

Hurlin, C. and R. Kierzenkowski. 2002. A Theoretical and Empirical Assessment of the Bank Lending Channel and Loan Market Disequilibrium in Poland. National Bank of Poland. Materials and Studies No. 22.

Hurlin, C. and R. Kierzenkowski. 2003. Credit Markt Disequilibrium in Poland: Can We Find What We Expect? Non-Stationarity and the "Min" Condition. William Davidson Working Paper No. 581.

Jakab, M. Z. and M. A. Kovács. 2003. Explaining the Exchange Rate Pass-Through in Hungary: Simulations with the NIGEM model. National Bank of Hungary Working Paper No. 5.

Jarociński, M. 2005. Responses to Monetary Policy Shocks in the East and the West of Europe. A Comparison. University of Pompeu Fabra. Mimeo.

Johansen, S. 1995. Likelihood-Based Inference in Cointegrated Vector Autoregressive Models. Oxford: Oxford University Press.

Juks, R. 2004. The Importance of the Bank Lending Channel in Estonia: Evidence from Microeconomic Data. Bank of Estonia Working Paper No. 6.

Kapinos, P. 2004. Resolving the price puzzle: Theory and evidence. Mimeo. http://www.econ.ilstu.edu/gawater/Seminars/kapinos.pdf

Kara, H., H. Küçük Tuğer, Ü. Özlale, B. Tuğer, D. Yavuz and E. M. Yücel. 2005. Exchange Rate PassThrough in Turkey: Has It Changed and to What Extent? Central Bank of the Republic of Turkey Working Paper No. 4. 
Kashyap, A. K., J. C. Stein and D. W. Wilcox. 1993. Monetary Policy and Credit Conditions: Evidence from the Composition of External Finance. American Economic Review 83(1). 78-98.

Kátay, G. and Z. Wolf. 2004. Investment Behavior. User Cost and Monetary Policy Transmission - the Case of Hungary. National Bank of Hungary Working Paper No. 12.

Kierzenkowski, R. 2004. Le canal étroit du crédit et la transmission de la politique monétaire: Analyse théorique et application au cas de la Pologne. PhD dissertation. University of Paris IX - Dauphine.

Kierzenkowski, R. 2005a. The Multi-Regime Bank Lending Channel and the Effectiveness of the Polish Monetary Transmission During Transition. Journal of Comparative Economics 33(1). 1-24.

Kierzenkowski, R. 2005b. Another View of the Bank Lending Channel Theory: The Bernanke and Blinder (1988) Model Revisited. Banque de France. Mimeo.

Kim, S. and N. Roubini. 2000. Exchange Rate Anomalies n the Industrial Countries: A Solution with a Structural VAR Approach. Journal of Monetary Economics 45(3). 561-586.

Kiss, G. and G. Vadas. 2005. The Role of the Housing Market in Monetary Transmission. National Bank of Hungary Background Studies No. 3.

Kohler, M., E. Britton and A. Yales. 2000. Trade Credit and the Monetary Transmission Mechanism. Bank of England Working Paper No. 115.

Korhonen, I. and P. Wachtel. 2005. A Note on Exchange Rate Pass-Through in CIS Countries. BOFIT Discussion Papers No. 2.

Kornai, J., E. Maskin and G. Roland. 2003. Understanding the Soft Budget Constraint. Journal of Economic Literature 41. 1095-1136.

Kot, A. 2004. Does Banking Sector Competitiveness Affect Interest Rate Pass-Through? Paper presented at the $3^{\text {rd }}$ Macroeconomic Policy Research Workshop on October 29-30, 2004. National Bank of Hungary

Köhler, M., J. Hommel and M. Grote. 2005. The Role of Banks in the Transmission of Monetary Policy in the

Baltics. Zentrum für Europäische Wirtschaftsforschung Discussion Paper No. 6.

Kuijs, L. 2002. Monetary Policy Transmission Mechanism and Inflation in the Slovak Republic. IMF Working Paper No. 80.

MacDonald, R. and J. Nagayasu 1999. The long-run relationship between real exchange rates and real interest rate differentials: A panel study. IMF Working Paper No. 37.

Maliszewski, W. 1999. VAR-ing Monetary Policy in Poland. CASE Studies\&Analyses No. 188.

Maliszewski, W. 2002. Monetary Policy in Transition: Structural Econometric Modelling and Policy Simulations. CASE Studies\&Analyses No. 246.

Maliszewski, W. 2003. Monetary Policy in Transition: Structural Econometric Modelling and Policy Simulations. CASE. Mimeo. 


\section{ECO/WKP(2008)62}

Markovic, B. 2004. Bank Capital Channels in the Monetary Transmission Mechanism. Bank of England. Mimeo.

Mateut, S. 2004. Trade Credit and Monetary Policy Transmission. Journal of Economic Surveys. 19(4). 654-670.

Mateut, S., S. Bougheas and P. Mizen. 2003. Trade Credit. Bank Lending and Monetary Policy Transmission. European University Institute Working Paper No. 2.

Matousek, R. and N. Sarantis. 2006. The Bank Lending Channel and Monetary Transmission in Central and Eastern Europe. Paper presented at the $61^{\text {st }}$ International Atlantic Economic Conference Berlin. March 15-19, 2006.

McCallum, B. T. 1999. Analysis of the Monetary Transmission Mechanism: Methodological Issues. NBER Working Paper No. 7395.

McCarthy, J. 1999. Pass-Through of Exchange Rates and Import Prices to Domestic Inflation in Some Industrialised Economies. BIS Working Paper No. 79.

McKenzie, M. D. 1999. The Impact of Exchange Rate Volatility on International Trade Flows. Journal of Economic Surveys 13. 71-106.

Mihaljek, D. and M. Klau. 2001. A Note on the Pass-Through from Exchange Rate and Foreign Price Changes to Inflation in Selected Emerging Market Economies. BIS Paper No. 8.

Mishkin, F S. 2001. The Transmission Mechanism and the Role of Asset Prices in Monetary Policy. NBER Working Paper No. 8617.

Mojon, B. and G. Peersman. 2001. A VAR Description of the Effects of Monetary Policy in the Individual Countries of the Euro Area. ECB Working Paper No. 92.

Molnár, J., M. Nagy and C. Horváth. 2007. A Structural Empirical Analysis of Retail Banking Competition: the Case of Hungary. Central Bank of Hungary Working Paper No. 1.

Nickisch, S. 2005. The Interest Rate Pass-Through in Lithuania. Free University of Berlin. Mimeo.

Nilsen, J. H. 2002. Trade Credit and the Bank Lending Channel. Journal of Money, Credit and Banking 34(1). 226-253.

Obstfeld, M. and K. Rogoff. 1996. Foundations of International Macroeconomics. Cambridge MA: MIT Press.

Oliner, S. D. and G. D. Rudebusch. 1996. Monetary Policy and Credit Conditions: Evidence from the Composition of External Finance: Comment. American Economic Review 86(1). 300-309.

Oomes, N. and F. Ohnsorge. 2005. Money Demand and Inflation in Dollarised Economies: The Case of Russia. Journal of Comparative Economics. 33(3). 462-483.

Opiela, T. P. 1999. The Responsiveness of Loan Rates to Monetary Policy in Poland: The Effects of Bank Structure. National Bank of Poland Materials and Studies No. 12. 
Peersman, G. and F. Smets. 2001. Are the effects of monetary policy in the euro area greater in recessions than in booms? ECB Working Paper No. 52.

Peersman, G. and F. Smets. 2002. The industry effects of monetary policy in the euro area. ECB Working Paper No. 165.

Pruteanu, A. 2004. The Role of Banks in the Czech Monetary Policy Transmission Mechanism. Checz National Bank Working Paper No. 3.

Rabanal, P. 2003. The Cost Channel of Monetary Policy: Further Evidence for the United States and the Euro Area. IMF Working Paper No. 149.

Rezessy, A. 2005. Estimating the Immediate Impact of Monetary Policy Shocks on the Exchange Rate and Other Asset Prices in Hungary. National Bank of Hungary. Occasional Papers No. 38.

Rodzko, R. 2004. Exchange Rate Pass-Through in the New EU Member States: Evidence from Micro Data. Bank of Lithuania. Mimeo.

Romer, C. and D. Romer. 1989. Does monetary policy matter? A new test in the spirit of Friedman and Schwartz. NBER Macroeconomic Annual No. 4. 121-170.

Sander, H. and S. Kleimeier. 2002. Asymmetric Adjustment of Commercial Bank Interest Rates in the Euro Area: An Empirical Investigation into Interest Rate Pass-Through. Kredit und Kapital 35(2). 161-192.

Sander, H. and S. Kleimeier. 2004a. Convergence in Euro-Zone Retail Banking? What Interest Rate PassThrough Tells Us about Monetary Policy Transmission. Competition and Integration. Journal of International Money and Finance 23(3). 461-492.

Sander, H. and S. Kleimeier. 2004b. Interest Rate Pass-Through in an Enlarged Europe: The Role of Banking Market Structure for Monetary Policy Transmission in Transition Economies. University of Maastricht. METEOR Research Memoranda No. 045.

Scalia, A. 2006. Is foreign exchange intervention effective? Some micro-analytical evidence from the Czech Republic. Banca d'Italia Temi di discussione No. 579.

Schmidt-Hebbel, K. and A. Werner. 2002. Inflation targeting in Brazil, Chile and Mexico: Performance, credibility and the exchange rate. Central Bank of Chile Working Paper No. 171.

Schmitz, B. 2004. What Role Do Banks Play in Monetary Policy Transmission in EU Accession Countries? Paper presented at the $3^{\text {rd }}$ Macroeconomic Policy Research Workshop on October 29-30, 2004. National Bank of Hungary.

Sims, C. A. 1992. Interpreting the Macroeconomic Time Series Facts: The Effects of Monetary Policy. European Economic Review 36(5). 975-1000.

Soto, C. and J. Selaive. 2003. Openness and Imperfect Pass-Through: Implications for the Monetary Policy. Central Bank of Chile Working Papers No. 216.

Taylor, J. 2000. Low Inflation. Pass-Through and the Pricing Power of Firms. European Economic Review 44(7). 1389-1408. 


\section{ECO/WKP(2008)62}

Tieman, A. 2004. Interest Rate Pass-Through in Romania and Other Central European Economies. IMF Working Paper No. 211.

Tornell, A. and F. Westermann. 2002. The Credit Channel in Middle Income Countries. NBER Working Paper No. 9355.

Van den Heuvel, S. J. 2002. The Bank Capital Channel of Monetary Policy. University of Pennsylvania. Mimeo.

Várhegyi, É. 2003. Bankverseny Magyarországon. (Competition in the Hungarian banking sector.) Közgazdasági Szemle 50. 1027-1048.

Világi, B. and J. Vincze. 1998. The Interest Rate Transmission Mechanism in Hungary 1991-1995. L. Halpern and C. Wyplosz (eds.). Hungary: Towards a Market Economy. Cambridge: Cambridge University Press. 54-84.

Vonnák, B. 2005. Estimating the Effect of Hungarian Monetary Policy within a Structural VAR Framework. National Bank of Hungary Working Paper No. 1.

Wang, H. 2001. Production Smoothing When Bank Loan Supply Shifts: The Role of Variable Capacity Utilization. Journal of Money, Credit and Banking 33(3). 749-766.

Weth, M. A. 2002. The Pass-Through from Market Interest Rates to Bank Lending Rates in Germany. Deutsche Bundesbank Discussion Paper No. 11.

Wróbel. E. 2001. The Monetary Transmission Mechanism and the Structural Modelling of Inflation at the National Bank of Poland. BIS Papers No. 8. 232-242.

Wróbel, E. and M. Pawlowska. 2002. Monetary Transmission in Poland: Some Evidence on Interest Rate and Credit Channels. National Bank of Poland. Materials and Studies No. 24 
ECO/WKP(2008)62

\section{WORKING PAPERS}

The full series of Economics Department Working Papers can be consulted at www.oecd.org/eco/Working_Papers/

653. The Economics of Climate Change Mitigation: Policies and Options for the Future (Forthcoming) Jean-Marc Burniaux, Jean Château, Romain Duval and Stéphanie Jamet

652. Reforming the labour market in Japan to cope with increasing dualism and population ageing (November 2008) Randall S. Jones

651. Enhancing the productivity of the service sector in Japan (November 2008) Randall S. Jones and Taesik Yoon

650. Reforming the tax system in Japan to promote fiscal sustainability and economic growth (November 2008) Randall S. Jones and Masahiko Tsutsumi

649. What Drives the NAIRU? Evidence from a Panel of OECD Countries (November 2008) Christian Gianella, Isabell Koske, Elena Rusticelli and Olivier Chatal

648. Short-term distributional effects of structural reforms: selected simulations in a DGSE framework (October 2008) Annabelle Mourougane and Lukas Vogel

647. Speed of adjustment to selected labour market and tax reforms (October 2008) Annabelle Mourougane, Lukas Vogel

646. The challenge of monetary policy in Turkey (October 2008) Olcay Çulha, Ali Çulha and Rauf Gönenç

645. Improving cost-effectiveness in the health-care sector in Iceland (October 2008) Hannes Suppanz

644. Understanding Russian regions' economic performance during periods of decline and growth - an Extreme Bound Analysis approach

(October 2008) Rüdiger Ahrend

643. Do tax structures affect aggregate economic growth? Empirical evidence from a panel of OECD countries

(October 2008) Jens Arnold

642. Accounting for one-off operations when assessing underlying fiscal positions (October 2008) Isabelle Joumard, Makoto Minegishi, Christophe André, Chantal Nicq and Robert Price

641. Do corporate taxes reduce productivity and investment at the firm level? Cross-country evidence from the Amadeus dataset (October 2008) Cyrille Schwellnus and Jens Arnold

640. The challenge of rapidly improving transport infrastructure in Poland (September 2008) Rafal Kierzenkowski 
639. Bridging the housing gap in Poland (September 2008), Rafal Kierzenkowski

638. Improving the business and investment climate in Indonesia (September 2008), Diego Moccero

637. Growth performance and policy challenges (September 2008), Luiz de Mello

636. A taxonomy of instruments to reduce greenhouse gas emissions and their interactions (September 2008), Romain Duval

635. Quantifying the effect of financial conditions on US activity (September 2008) Stéphanie Guichard and David Turner

634. Have long-term financial trends changed the transmission of monetary policy (September 2008), Stéphanie Guichard and David Turner

633. Raising education achievement and breaking the cycle of inequality in the United Kingdom (August 2008) Anne-Marie Brook

632. The euro changeover in the Slovak Republic: implications for inflation and interest rates (August 2008) Felix Hüfner and Isabell Koske

631. Tax reform for efficiency and fairness in Canada (August 2008) Alexandra Bibbee

630. Reforming the Polish Tax System to Improve its Efficiency (August 2008) Alain de Serres

629. Modernising Canada's Agriculture Policies (August 2008) Peter Jarrett and Shuji Kobayakawa

628. Recent trends and structural breaks in US and EU15 labour productivity growth (August 2008) Laure Turner and Hervé Boulhol

627. Health Status Determinants: Lifestyle, Enviroment, Health Care Resources and Efficiency (August 2008) Isabelle Joumard, Christophe André, Chantal Nicq and Olivier Chatal

626. Market Mechanisms in Public Service Provision (August 2008) Hansjörg Blöchliger

625. Improving human capital formation in India (July 2008) Sean M. Dougherty and Richard Herd 